\title{
Proteolytic activation of proapoptotic kinase protein kinase $C \delta$ by tumor necrosis factor a death receptor signaling in dopaminergic neurons during neuroinflammation
}

Richard Gordon, Vellareddy Anantharam, Anumantha G Kanthasamy and Arthi Kanthasamy*

\begin{abstract}
Background: The mechanisms of progressive dopaminergic neuronal loss in Parkinson's disease (PD) remain poorly understood, largely due to the complex etiology and multifactorial nature of disease pathogenesis. Several lines of evidence from human studies and experimental models over the last decade have identified neuroinflammation as a potential pathophysiological mechanism contributing to disease progression. Tumor necrosis factor a (TNF) has recently emerged as the primary neuroinflammatory mediator that can elicit dopaminergic cell death in PD. However, the signaling pathways by which TNF mediates dopaminergic cell death have not been completely elucidated.

Methods: In this study we used a dopaminergic neuronal cell model and recombinant TNF to characterize intracellular signaling pathways activated during TNF-induced dopaminergic neurotoxicity. Etanercept and neutralizing antibodies to tumor necrosis factor receptor 1 (TNFR1) were used to block TNF signaling. We confirmed the results from our mechanistic studies in primary embryonic mesencephalic cultures and in vivo using the stereotaxic lipopolysaccharide (LPS) model of nigral dopaminergic degeneration.
\end{abstract}

Results: TNF signaling in dopaminergic neuronal cells triggered the activation of protein kinase C $\delta$ (PKC $\delta$ ), an isoform of the novel PKC family, by caspase-3 and caspase-8 dependent proteolytic cleavage. Both TNFR1 neutralizing antibodies and the soluble TNF receptor Etanercept blocked TNF-induced PKC $\delta$ proteolytic activation. Proteolytic activation of PKC $\delta$ was accompanied by translocation of the kinase to the nucleus. Notably, inhibition of PKC $\delta$ signaling by small interfering (si)RNA or overexpression of a PKC $\delta$ cleavage-resistant mutant protected against TNF-induced dopaminergic neuronal cell death. Further, primary dopaminergic neurons obtained from PKC $\delta$ knockout $(-/-)$ mice were resistant to TNF toxicity. The proteolytic activation of PKC $\delta$ in the mouse substantia nigra in the neuroinflammatory LPS model was also observed.

Conclusions: Collectively, these results identify proteolytic activation of PKC $\delta$ proapoptotic signaling as a key downstream effector of dopaminergic cell death induced by TNF. These findings also provide a rationale for therapeutically targeting PKC $\delta$ to mitigate progressive dopaminergic degeneration resulting from chronic neuroinflammatory processes.

Keywords: Apoptosis, dopaminergic degeneration, Parkinson's disease, PKC 8 , proteolytic activation, neurotoxicity, neuroinflammation, nuclear translocation, TNFa

\footnotetext{
* Correspondence: arthik@iastate.edu

Parkinson Disorders Research Program, lowa Center for Advanced

Neurotoxicology, Department of Biomedical Sciences, lowa State University,

Ames IA 50011, USA
} 


\section{Background}

Parkinson's disease (PD) is a debilitating neurodegenerative movement disorder affecting around $2 \%$ of the population over the age of $60[1,2]$. The key pathological hallmark of the disease is a loss of dopaminergic (DA) neurons in the substantia nigra of the midbrain, resulting in a depletion of striatal dopamine that is clinically manifest as a range of motor and non-motor deficits [3]. Recent studies indicate that a sustained neuroinflammatory response is initiated in the substantia nigra pars compacta (SNpc) during early stages of dopaminergic degeneration, and remains evident in postmortem PD brains with increased microgliosis, dystrophic astrocytes and lymphocyte infiltration [4-6]. Compelling evidence over the last decade from animal models, in vitro studies and PD patients has demonstrated that the protracted neuroinflammation that occurs in the SNpc can exacerbate the degeneration of vulnerable dopaminergic neurons. However, the molecular mediators and mechanisms underlying the neuroinflammatory processes remain to be established.

Tumor necrosis factor $\alpha$ (TNF) has recently emerged as an important neuroinflammatory mediator linked to dopaminergic degeneration in PD. Increased levels of TNF are present in the SNpc and the CSF of postmortem PD patients, and genetic polymorphisms in the TNF gene locus have been linked to the development of PD [7-12]. Increased TNF is also well documented in rodent and nonhuman primate models of PD induced by neurotoxic insults and in transgenic models [13,14]. Importantly, ablation of TNF signaling using knockout mice for TNF $\alpha$ or its receptors has been shown to attenuate 1-methyl-4phenyl-1,2,3,6-tetrahydropyridine (MPTP)-induced dopaminergic degeneration $[15,16]$. Furthermore, genetic or pharmacological inhibition of soluble TNF signaling with dominant negative mutants is protective against 6hydroxydopamine and lipopolysaccharide (LPS)-induced dopaminergic degeneration in vivo $[17,18]$. Conversely, the chronic expression of low levels of TNF in the substantia nigra of rats induced by a viral vector causes progressive dopaminergic degeneration with delayed motor deficits [19]. Together, these independent findings strongly implicate TNF in the progressive loss of dopaminergic neurons in PD. However, the signaling mechanisms by which TNF can mediate dopaminergic degeneration have not been characterized.

Protein kinase C $\delta$ (PKC $\delta$ ), a member of the novel PKC isoform family, is highly expressed in nigral dopaminergic neurons [20]. Recent studies from our laboratory and others have shown that PKC $\delta$ is proteolytically activated by caspase- 3 during dopaminergic cell death and that genetic or pharmacological targeting of PKC $\delta$ can protect against dopaminergic degeneration in PD models [21-24]. In this paradigm, increased oxidative stress in dopaminergic neurons results in proteolytic activation of PKC $\delta$ by caspase-3 downstream of the intrinsic mitochondrial apoptotic pathway. The proteolytic cleavage of PKC $\delta$ by caspase- 3 persistently activates the kinase as an effector of dopaminergic cell death. However, PKC $\delta$ activation by extrinsic neuroinflammatory mediators such as TNF has not been studied and would be relevant to the progression of PD by neuroinflammatory mechanisms. Since TNF also activates caspase- 3 by signaling through its death receptors, we determined if PKC $\delta$ is proteolytically activated during TNF-induced dopaminergic cell death and in the mouse substantia nigra (SN). Our findings herein identify PKC $\delta$ as a key downstream target of TNF death receptor signaling in dopaminergic neurons and demonstrate a novel link between neuroinflammatory mechanisms and progressive dopaminergic degeneration.

\section{Methods}

\section{Chemicals and reagents}

RPMI, neurobasal medium, B27 supplement, fetal bovine serum, L-glutamine, Sytox assay dye, IR-dye-tagged secondary antibodies, penicillin, streptomycin and other cell culture reagents were purchased from Invitrogen (Gaithersburg, MD, USA). Recombinant rat TNF, LPS (Escherichia coli 0111:B4) and cytosine arabinoside were purchased from Sigma-Aldrich (St Louis, MO, USA). Recombinant murine TNF and the tumor necrosis factor receptor 1 (TNFR1) neutralizing antibody were from R\&D Systems (Minneapolis, MN, USA). Etanercept (Enbrel) was purchased from Amgen, Inc. (Thousand Oaks, CA, USA). Antibodies for rabbit PKC $\delta$ and caspase-8 were from Santa Cruz Biotechnology, Inc. (Santa Cruz, CA, USA). Tyrosine hydroxylase (TH) antibody was purchased from Chemicon (Temecula, CA, USA) and microtubule-associated protein 2 (MAP-2) antibody from Cell Signaling Technologies (Beverly, MA, USA). ${ }^{32}$ P-ATP was purchased from Perkin Elmer (Boston, MA, USA) and the AMAXA Nucleofector kit from Lonza (Basel, Switzerland). Caspase assay substrates and inhibitors were purchased from MP Biomedicals (Solon, OH, USA). The DNA fragmentation assay kit was purchased from Roche Applied Science and the Bradford protein assay kit was purchased from Bio-Rad Laboratories (Hercules, CA, USA).

\section{Culture and treatment paradigm for rat dopaminergic N27 cells}

The development and culture conditions of the N27 clonal dopaminergic cell line have been described previously $[21,24,25]$. Similar culture conditions were used in this study. Briefly, cells were cultured in RPMI 1640 medium containing $10 \%$ heat inactivated fetal bovine serum, $2 \mathrm{mM} \mathrm{L-glutamine,} \mathrm{penicillin} \mathrm{(100} \mathrm{units} / \mathrm{ml})$, and streptomycin $(100 \mu \mathrm{g} / \mathrm{ml})$. Cells were maintained in a humidified atmosphere of $5 \% \mathrm{CO}_{2}$ at $37^{\circ} \mathrm{C}$. RPMI 
medium containing $2 \%$ fetal bovine serum was used for the TNF treatment. Cells were washed twice in $2 \%$ RPMI serum and then treated with the indicated doses of recombinant rat TNF.

\section{Primary mouse mesencephalic neuron cultures}

Primary neurons were cultured from ventral mesencephalon tissue of gestational 14-day (E14) mouse embryos, as described previously $[21,26]$ with some modifications. The ventral mesencephalon was dissected under a microscope and collected in ice-cold Dulbecco's modified Eagle medium F-12 complete medium (DMEM-F12 supplemented with $10 \%$ heat-inactivated fetal bovine serum (FBS), $50 \mathrm{U} / \mathrm{mL}$ penicillin, $50 \mu \mathrm{g} / \mathrm{mL}$ streptomycin, $2 \mathrm{mML}$-glutamine, $100 \mu \mathrm{M}$ non-essential amino acids, and $2 \mathrm{mM}$ sodium pyruvate). The tissue was then dissociated using trypsin-ethylenediaminetetra-acetic acid (EDTA) $(0.25 \%)$ for 15 minutes at $37^{\circ} \mathrm{C}$. Trypsinization was stopped by adding an equal volume of DMEMF12 complete medium and dissociated tissue was washed in the same medium to remove residual trypsin. The DMEM-F12 medium was aspirated out and the tissue triturated in neurobasal medium containing B-27 antioxidant supplement, $500 \mu \mathrm{ML}$-glutamine, $100 \mathrm{U} / \mathrm{ml}$ penicillin, and $100 \mu \mathrm{g} / \mathrm{ml}$ streptomycin. After a single cell suspension was obtained, cells were passed through a $70 \mu \mathrm{m}$ nylon mesh cell strainer to remove tissue debris and aggregates. Cells were counted using a Beckman Coulter ViCell XR automated cell counter and then plated at an equal density $\left(0.8 \times 10^{6}\right.$ cells per well $)$ in 24 well plates containing coverslips precoated with poly-D-lysine $(100 \mu \mathrm{g} / \mathrm{ml})$. Cultures were maintained in neurobasal medium with B-27 antioxidant supplements and cytosine arabinoside $(5 \mu \mathrm{M})$ was added to inhibit glial proliferation. Cultures were grown in a humidified $\mathrm{CO}_{2}$ incubator $(5 \%$ $\mathrm{CO}_{2}, 37^{\circ} \mathrm{C}$ ) and the medium was changed every 2 days. Approximately 4-day-old to 5-day-old cultures were used for treatment. The neuronal cultures were verified to be around $98 \%$ free of glial cells at the time of treatment by using immunocytochemistry for MAP-2, glial fibrillary acidic protein (GFAP) and ionized calcium binding adaptor molecule 1 (iba1) as markers of neurons, astrocytes and microglia, respectively [27]. For TNF treatment, cultures were switched to serum-free neurobasal medium without antioxidant supplements and treated for $48 \mathrm{~h}$. Recombinant murine TNF $(30 \mathrm{ng} / \mathrm{ml})$ was added at the beginning of the treatment and re-added again $24 \mathrm{~h}$ later. At the end of the treatment, primary cultures were processed for TH immunocytochemistry and neurotransmitter uptake assays.

\section{DNA fragmentation and Sytox assays}

DNA fragmentation was quantified using the Cell Death Detection ELISA Plus assay kit (Roche Applied Science), as described in our previous publications [21,22,24]. This highly sensitive and reliable assay detects and quantifies early changes in apoptosis based on the amounts of histone-associated low molecular weight DNA released into the cytoplasm of cells. Briefly, N27 cells were plated in six-well plates at $0.8 \times 10^{6}$ cells/well and treated the next day with TNF for $16 \mathrm{~h}$. Cells were collected using a cell scraper and centrifuged at $400 \times \mathrm{g}$ for 5 minutes. The cells were gently lysed using the lysis buffer provided with the kit. The lysate then was spun down again at $200 \mathrm{~g}$ for 10 minutes to pellet the nuclear fraction, and the supernatant was collected and used to measure DNA fragmentation according to the manufacturer's instructions for the ELISA protocol. The absorbance at $405 \mathrm{~nm}$ was measured against an 2,2'-azino-bis(3-ethylbenzothiazoline-6-sulfonic acid (ABTS) solution as a blank (reference wavelength approximately $490 \mathrm{~nm}$ ) using a Synergy-2 Multi-Mode Microplate Reader (BioTek Instruments, Inc). The absorbance values were normalized to the amount of protein present in the lysates and the data expressed as percent control. The Sytox cytotoxicity assay was performed using the Sytox green dye (Molecular Probes). The assay is based on the principle that live cells with intact plasma membranes can exclude the Sytox dye, which selectively enters cells with a compromised membrane and emits bright green fluorescence on binding to DNA [28]. N27 cells were grown in 24 well plates and $1 \mu \mathrm{M}$ of the Sytox dye was added at the time of treatment. Cells were treated for $16 \mathrm{~h}$ with TNF and pretreated with etanercept. The increase in green fluorescence, as a result of TNF cytotoxicity, was measured using a fluorescence microplate reader (Spectramax Gemini, Molecular Devices) at an excitation of $485 \mathrm{~nm}$ and $538 \mathrm{~nm}$ emission. Phase contrast and fluorescence images of matching fields were captured on the same cells to visualize the toxicity in N27 cells.

\section{Caspase- 3 enzymatic activity assays}

Enzymatic assays for caspase-3 activity were performed as described previously $[22,24]$ using acetyl-DEVD-amino-4trifluoromethylcoumarin (Ac-DEVD-AFC, $25 \mu \mathrm{m}$ ) as the fluorometric substrate for the reaction. N27 cells were treated with TNF $(30 \mathrm{ng} / \mathrm{ml})$ for $6 \mathrm{~h}$ or pretreated with etanercept $(5 \mu \mathrm{g} / \mathrm{ml})$ for 30 minutes. Following treatment, $100 \mu \mathrm{l}$ of cell extract was incubated with $5 \mu \mathrm{l}$ of the fluorescence substrate and then incubated at $37^{\circ} \mathrm{C}$ for $1 \mathrm{~h}$ while being protected from light. The fluorescence signal generated upon cleavage of the AFC peptide substrate by caspase- 3 was measured at $510 \mathrm{~nm}$ with an excitation of $400 \mathrm{~nm}$ using a Synergy-2 Multi-Mode microplate reader. Protein concentrations were determined using the Bradford assay. Raw values were normalized using protein concentrations and expressed as percent control. 


\section{Confocal immunofluorescence microscopy for PKC $\delta$ translocation}

N27 dopaminergic cells were plated on poly-D-lysine $(100 \mu \mathrm{g} / \mathrm{ml})$ coated coverslips in 24 well plates at $0.2 \times 10^{6}$ cells per well. The next day, the cells were treated with $30 \mathrm{ng} / \mathrm{ml}$ of TNF for $6 \mathrm{~h}$ in $2 \%$ serum RPMI medium. Cells were fixed in $4 \%$ paraformaldehyde for 20 minutes and washed five times in PBS. The cells were blocked and permeabilized with blocking buffer (5\% goat serum, $0.2 \%$ Triton $\mathrm{X}$, and $0.05 \%$ Tween-20 in PBS) for $1 \mathrm{~h}$ and then incubated overnight at $4{ }^{\circ} \mathrm{C}$ with a rabbit polyclonal PKC $\delta$ antibody $(1: 1,000)$ that recognizes a C-terminal epitope present in both the native and the proteolytically cleaved protein. The cells were then washed five times in PBS and then incubated with secondary antibody (1:2,000, Alexa 488 goat anti-rabbit) for $1 \mathrm{~h}$ at room temperature. Negative controls for non-specific staining that contained secondary antibody alone were used on parallel wells to ensure specificity of the fluorescent signals obtained. The cells were then washed five times in PBS and the nucleus was labeled using the TOPRO 3 dye. The cells were then washed three more times in PBS and coverslips were mounted using the ProLong Gold antifade reagent (Molecular Probes). Confocal images were acquired with a Nikon EZ-C1 confocal system using the $488 \mathrm{~nm}$ and $633 \mathrm{~nm}$ lasers to visualize PKC $\delta$ and TOPRO 3, respectively. Fluorescence spatial intensity plots along the XY plane for PKC $\delta$ localization (green channel) and the nucleus (blue channel) were generated using the Nikon EZC1 software to show nuclear translocation.

\section{Fluorescent Western blotting}

Lysates from N27 cells and brain tissue were prepared using a modified radio immunoprecipitationassay (RIPA) buffer and normalized for equal amounts of protein using the BCA protein assay (Pierce Biotechnology). Gel loading dye was added to the lysates and stored in aliquots at $-80^{\circ} \mathrm{C}$. Equal amounts of protein (30 to $60 \mu \mathrm{g}$ ) were loaded for each sample and separated on either $12 \%$ or $15 \%$ SDS-PAGE gels, depending on the molecular weight of the target protein. After separation, the proteins were transferred to nitrocellulose membranes and nonspecific binding sites were blocked by incubating the membranes in fluorescent Western blocking buffer (Rockland Immunochemicals) for $1 \mathrm{~h}$, and then they were probed with primary antibodies overnight at $4^{\circ} \mathrm{C}$. Primary antibodies used were rabbit polyclonal PKC $\delta$ (1:500), mouse monoclonal TH $(1: 2,000)$, rabbit polyclonal caspase-8 $(1: 200)$. $\beta$-Actin $(1: 5,000)$ was used as the loading control. After incubation, membranes were washed three times with PBS containing $0.05 \%$ Tween and IR-dye tagged secondary antibodies (1:5,000; Molecular Probes) were added. Membranes were visualized on the Odyssey infra-red imaging system.

\section{PKCס immunoprecipitation (IP)-kinase assays}

The PKC $\delta$ enzymatic kinase activity assay was performed as described previously [21,22,29]. Briefly, N27 cells or substantia nigra tissues were washed in ice-cold PBS and then resuspended in a mild RIPA lysis buffer containing protease and phosphatase inhibitor cocktail (Pierce Biotechnology). The lysates were placed on ice for $20 \mathrm{~min}$ utes, sonicated gently and centrifuged at 13,000 rpm for 45 minutes. The supernatant was collected and protein concentration was determined using the Bradford assay [30]. All samples were made up to a concentration of $2 \mu \mathrm{g} / \mathrm{ml}$, and $500 \mu \mathrm{g}$ of total protein in a $250 \mu \mathrm{l}$ volume was immunoprecipitated overnight at $4^{\circ} \mathrm{C}$ using $5 \mu \mathrm{g}$ of the PKC $\delta$ antibody. The next day, the protein A-agarose beads (Sigma-Aldrich) were added and the samples were incubated for $1 \mathrm{~h}$ at room temperature. The protein A-bound antibody complexes were then washed three times in $2 \times$ kinase assay buffer $(40 \mathrm{mM}$ Tris, $\mathrm{pH}$ 7.4, $20 \mathrm{mM} \mathrm{MgCl}$, $20 \mu \mathrm{M}$ ATP, and $2.5 \mathrm{mM} \mathrm{CaCl}_{2}$ ), and then resuspended in $40 \mu \mathrm{l}$ of the same buffer. The kinase reaction was started by adding $40 \mu \mathrm{l}$ of the reaction buffer containing $0.4 \mathrm{mg}$ of histone $\mathrm{H} 1,50 \mu \mathrm{g} / \mathrm{ml}$ phosphatidylserine, $4 \mu \mathrm{M}$ dioleoylglycerol, and $10 \mu \mathrm{Ci}$ of $\left[\gamma^{-32} \mathrm{P}\right] \mathrm{ATP}$ at $3,000 \mathrm{Ci} / \mathrm{mM}$ to the immunoprecipitated samples. The samples were incubated for 10 minutes at $30^{\circ} \mathrm{C}$. The kinase reaction was stopped by adding $2 \times$ SDS loading buffer and boiling the samples for 5 minutes. The proteins were separated on a $12 \%$ SDS-PAGE gel and the phosphorylated histone $\mathrm{H} 1$ bands were scanned using a Fujifilm FLA 5000 imager. Image analysis and band quantification were performed using the Fujifilm Multigauge software package (Fujifilm USA, Stamford, CT).

\section{Transfection with siRNA and cleavage-resistant PKC $\delta^{\text {D327A }}-$ CRM mutant}

Design and synthesis of PKC $\delta$ siRNA are described in our previous publications [21,31]. N27 cells were transfected with 40 to $50 \mathrm{nM}$ of either PKC or scramble siRNA duplexes using the AMAXA Nucleofector kit, according to the manufacturer's instructions. Transfected cells were counted using a Vi-Cell XR automated cell counter and seeded at equal density $\left(0.5 \times 10^{6}\right.$ cells/well $)$ into six-well plates. The cells were treated $24 \mathrm{~h}$ after transfection to allow for optimal knockdown of gene expression. At the end of the treatment, cells were collected and used for the DNA fragmentation assay as described above. For studies with the PKC $\delta$ cleavageresistant mutant $\left(\mathrm{PKC} \delta^{\mathrm{D} 327 \mathrm{~A}}-\mathrm{CRM}\right)$, stable $\mathrm{N} 27$ cell lines overexpressing either the mutant $\mathrm{PKC} \delta^{\mathrm{D} 327 \mathrm{~A}}$ protein or the $\beta$-galactosidase (Lac Z) protein as the vector control were prepared as described in our publications [32]. Both 
cell lines were cultured in the presence of blasticidin for three passages before treatment. Expression of the PKC $\delta$ CRM-mutant and the Lac $\mathrm{Z}$ vector control at the time of treatment was confirmed by staining for the V5-epitope. Cells were plated at equal density $\left(0.7 \times 10^{6}\right.$ cells per well) in six-well plates and allowed to grow overnight. The next day, cells were treated with $30 \mathrm{ng} / \mathrm{ml}$ of TNF for $16 \mathrm{~h}$ and processed for the DNA fragmentation assay.

\section{Dopamine uptake assays}

Uptake assays for tritiated dopamine on primary EVM cultures were performed according to previously published protocols [17,33,34]. After TNF treatment, the primary neuron cultures from PKC $\delta$ wild type $(+/+)$ and knockout $(-/-)$ mice were washed three times with $0.5 \mathrm{ml}$ of warm Krebs-Ringer buffer (16 mM sodium phosphate, $120 \mathrm{mM}$ $\mathrm{NaCl}, 4.7 \mathrm{mM} \mathrm{KCl}, 1.8 \mathrm{mM} \mathrm{CaCl}, 1.2 \mathrm{mM} \mathrm{MgSO}$, $1.3 \mathrm{mM}$ EDTA, and $5.6 \mathrm{mM}$ glucose; $\mathrm{pH}$ 7.4). The cultures were then incubated with $5 \mu \mathrm{M}\left[{ }^{3} \mathrm{H}\right]$-dopamine $(30 \mathrm{Ci} /$ $\mathrm{mmol}$ ) in Krebs-Ringer buffer at $37^{\circ} \mathrm{C}$ for 20 minutes. The cells were then washed three times with ice-cold Krebs-Ringer buffer and collected in $1 \mathrm{ml}$ of $1 \mathrm{~N} \mathrm{NaOH}$. Scintillation fluid was added to a total volume of $5 \mathrm{ml}$ and radioactivity counts were measured using a Tri-Carb Liquid Scintillation counter (Packard). In parallel wells, the nonspecific uptake of dopamine was determined by incubation with $10 \mu \mathrm{M}$ mazindol. The nonspecific uptake values were subtracted to obtain the data for high affinity neurotransmitter uptake. Data from dopamine uptake studies were expressed as percent control.

\section{TH-positive cell counts and immunofluorescence}

After TNF treatment, primary neuron cultures from PKC $\delta$ wild type $(+/+)$ and PKC $\delta$ knockout $(-/-)$ mice were fixed in $4 \%$ paraformaldehyde and permeabilized with PBS containing $2 \%$ bovine serum albumin (BSA), $0.2 \%$ Triton X-100 and $0.05 \%$ Tween-20. Blocking buffer (PBS with $2 \%$ BSA) was added for $1 \mathrm{~h}$ at room temperature and primary antibodies for $\mathrm{TH}(1: 1,000)$ and MAP-2 $(1: 1,000)$ were diluted in blocking buffer and incubated overnight at $4^{\circ} \mathrm{C}$. The next day, cells were washed in PBS four times and incubated with appropriate Alexa-dye conjugated secondary antibodies for $1 \mathrm{~h}$ at room temperature. After several washes, the samples were counterstained with Hoechst to label the nucleus, and coverslips were mounted using the Prolong Antifade (Molecular Probes) mounting medium. Images were acquired using a Nikon inverted fluorescence microscope (model TE-2000U) equipped with a SPOT digital camera system (Diagnostic Instruments, Sterling Heights, MI, USA). Image analysis was performed using the Metamorph software package (Universal Imaging Systems, PA, USA).

\section{Stereotaxic infusion of LPS into the mouse substantia nigra} A single dose LPS injection model that was previously described [35] was used to induce delayed, progressive loss of dopaminergic neurons in the substantia nigra. C57/BL/6 mice (8 weeks old, $\mathrm{n}=6$ per group) were anesthetized with a mixture of ketamine-xylazine $(100 \mathrm{mg} / \mathrm{kg}, 10 \mathrm{mg} / \mathrm{kg})$ and carefully immobilized on a stereotaxic apparatus (Benchmark Angle One, Leica Microsystems). The skin above the skull was prepped with alcohol and an incision was made to expose the skull. A single burr hole was carefully drilled at the injection site for the right $\mathrm{SN}$ and ophthalmic gel was used to protect the eyes. The stereotaxic coordinates for the injection site were anteroposterior (AP) $-3.3 \mathrm{~mm}$, mediolateral (ML) $-1.2 \mathrm{~mm}$, dorsoventral (DV) $-4.6 \mathrm{~mm}$ from bregma [36]. A stainless steel cannula attached to a $5 \mu \mathrm{l}$ Hamilton syringe was carefully inserted into the hole drilled at the injection site and a single dose of $5 \mu \mathrm{g}$ LPS in a $1 \mu \mathrm{l}$ volume was injected at the rate of $0.5 \mu \mathrm{l}$ per minute. The needle was left in place for another 5 minutes to prevent retrograde flow of liquid along the needle track. Control mice were injected in an identical manner with equal volumes of saline. After surgery, the skin was sutured and carefully held in place using sterile, nonpyrogenic stainless steel clips (Autoclip Wound Closing System, Braintree Scientific, Inc). Mice were allowed to recover on a heating pad (Braintree Scientific, Inc) and were carefully monitored through recovery from anesthesia. All animal procedures were approved by the Iowa State University Institutional Animal Care and Use Committee (IACUC).

\section{Data analysis}

Data analysis was performed using the Prism 4.0 software package (GraphPad Software, San Diego, CA, USA). The data were first analyzed using one-way analysis of variance (ANOVA) and then Bonferroni's post-test was performed to compare all treatment groups. Differences of $P<0.05$ were considered statistically significant. The Student's $t$ test was used when differences between two groups were being compared.

\section{Results}

TNF is neurotoxic to dopaminergic N27 cells and activates caspase- 8 and caspase- 3

To determine the downstream mechanisms underlying TNF stimulation in dopaminergic neuronal cells, we used the N27 dopaminergic neuronal cell model, which has been widely used by several laboratories to study dopaminergic degeneration related to PD [21,24,25]. First we examined the neurotoxic effect of TNF on N27 dopaminergic neuronal cells. The Sytox assay and the sensitive DNA fragmentation ELISA were used to quantify TNF cytotoxicity. TNF $(30 \mathrm{ng} / \mathrm{ml})$ induced 
significant increases in Sytox fluorescence and cell death morphology, which could be blocked using the TNF neutralizing drug etanercept (Figure 1A,B). Since TNF cytotoxicity can proceed through activation of caspases in various cell types, we examined caspase activation downstream of TNF signaling. High levels of the pro-caspase- 8 protein were detected in $\mathrm{N} 27$ cells, and TNF treatment induced activation of caspase- 8 at $3 \mathrm{~h}$, with increased accumulation of the active p20 fragment (Figure 1C,D). Again, the activation of caspase- 8 was attenuated by pretreatment with the TNF inhibitor etanercept. Since caspase-3 is an important effector caspase downstream of TNF signaling, and is known to be activated in PD models and in the human PD brain [37,38], we studied caspase-3 activation in TNF-treated N27 cells. We found that TNF treatment for $6 \mathrm{~h}$ caused activation of caspase-3, which could be blocked by pretreatment with etanercept and the caspase- 8 inhibitor IETD-fmk (Figure 1E). These results indicate that caspase- 3 is activated in a caspase- 8 dependent manner downstream of TNF death receptor signaling in dopaminergic neuronal cells. Next we used the sensitive DNA fragmentation ELISA assay to quantify TNF cell-death signaling. Exposure to TNF (30 $\mathrm{ng} / \mathrm{ml})$ for $16 \mathrm{~h}$ resulted in a threefold increase in DNA fragmentation compared to untreated controls (Figure 1F). Pretreatment with the TNF-neutralizing drug etanercept or a caspase-8 inhibitor (IETD-fmk) almost completely blocked TNF-induced DNA fragmentation, indicating that canonical TNF death receptor signaling through activation of caspase- 8 is involved in the dopaminergic neurotoxicity caused by sustained exposure to TNF. In preliminary studies, we found that doses as low as $10 \mathrm{ng} / \mathrm{ml}$ TNF could induce detectable toxicity in N27 dopaminergic cells. We chose a $30 \mathrm{ng} / \mathrm{ml}$ dose of TNF based on previous in vitro studies [26] and because this concentration induced a consistent neurotoxic response in vitro. The dose range of TNF used in our mechanistic studies is high compared to the levels of circulating TNF in the serum and CSF of PD patients [39-41] due to the fact that high doses are necessary to elicit a detectable response in cell culture models within a shorter timeframe. Also, the circulating TNF has a short half-life and therefore, it does not reflect the elevated levels of tissue TNF in the substantia nigra. The TNF concentration at 10 to $60 \mathrm{ng} / \mathrm{ml}$ used in our study is consistent with doses used in cell culture experiments by other researchers $[17,26]$.

\section{TNF induces proteolytic activation of protein kinase $\mathrm{C} \delta$ in dopaminergic neuronal cells}

We recently showed that $\mathrm{PKC} \delta$, a proapoptotic kinase belonging to the novel PKC isoform family, is highly expressed in dopaminergic neurons [21,42]. Further, we demonstrated that PKC $\delta$ is activated by caspase- 3 mediated proteolytic cleavage at its hinge region following mitochondrial oxidative stress, resulting in persistent activation of the kinase and amplification of apoptotic signals in dopaminergic neurons [21,22,24]. Since PKC $\delta$ activation by the extrinsic apoptotic pathway in dopaminergic cells or its role in neuroinflammation-induced dopaminergic neurotoxicity has not been examined, we tested if $\mathrm{PKC} \delta$ can be activated by caspase- 3 during TNF-induced death of dopaminergic neuronal cells and function as a downstream apoptotic effector. Interestingly, TNF treatment caused a time and dose dependent proteolytic activation of PKC $\delta$ that was detectable $3 \mathrm{~h}$ after treatment and increased at $6 \mathrm{~h}$ (Figure 2A,B). Dose response studies at the $6 \mathrm{~h}$ time point showed that doses as low as $10 \mathrm{ng} / \mathrm{ml}$ of TNF could induce detectable proteolytic activation of $\mathrm{PKC} \delta$, which increased substantially with $30 \mathrm{ng} / \mathrm{ml}$ TNF. Higher doses of TNF $(60 \mathrm{ng} / \mathrm{ml})$ did not significantly increase $\mathrm{PKC} \delta$ cleavage further (Figure $2 \mathrm{C}$, D). Since caspase- 8 and caspase- 3 were activated by TNF in these cells, we tested if $\mathrm{PKC} \delta$ proteolytic activation was mediated by this signaling pathway using the specific caspase inhibitors DEVD-fmk and IETD-fmk. Pretreatment with the caspase- 8 and caspase- 3 inhibitors suppressed TNF-induced proteolytic activation of protein kinase $C \delta$ (Figure 2E,F). Taken together, these results suggest that the proapoptotic kinase PKC $\delta$ could be activated by caspase- 8 and caspase- 3 dependent proteolytic cleavage during TNF toxicity in dopaminergic neuronal cells. The proteolytically cleaved PKC $\delta$ fragment appeared as a doublet band in Western blots in our experiments. Several alternate splice forms of PKC $\delta$ have been reported, including a caspase-3 cleavage-resistant form and a truncated form lacking the regulatory domain [43,44]. Also, the C-terminal catalytic domain of PKC $\delta$ contains multiple phosphorylation sites. Because the antibody used in these studies recognizes the C-terminal catalytic domain, it is possible that the doublet band of the cleaved product represents a post-translational modification of the cleavage product or one of the truncated PKC $\delta$ alternate splice forms.

\section{Proteolytic activation of PKC $\delta$ by TNF signaling activates the kinase}

Unlike other proteins for which proteolytic cleavage can result in loss of function or inactivation, the proteolytic cleavage of $\mathrm{PKC} \delta$ by caspase-3 during oxidative stressinduced dopaminergic cell death has been shown to persistently activate the kinase $[21,22,24,45]$. We used IP-kinase assays and Western blotting to determine if TNF-induced proteolytic activation of PKC $\delta$ leads to sustained activation of the kinase in N27 dopaminergic cells. As shown in Figure 3A, treatment with TNF for $6 \mathrm{~h}$ significantly increased proteolytic cleavage of $\mathrm{PKC} \delta$, which was blocked by pretreatment with Etanercept or a TNFR1 receptor-neutralizing antibody. PKC $\delta$ IP-kinase 


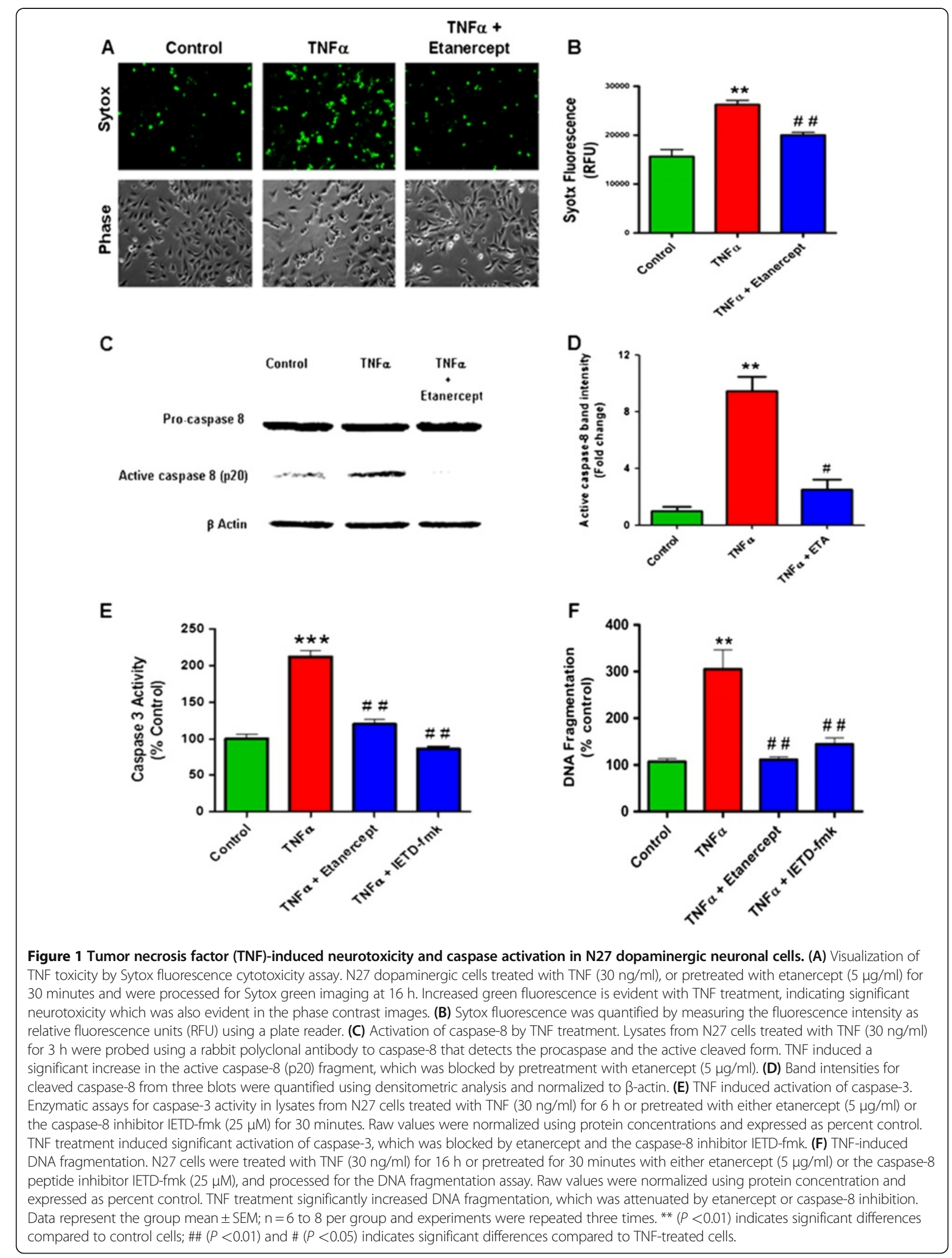




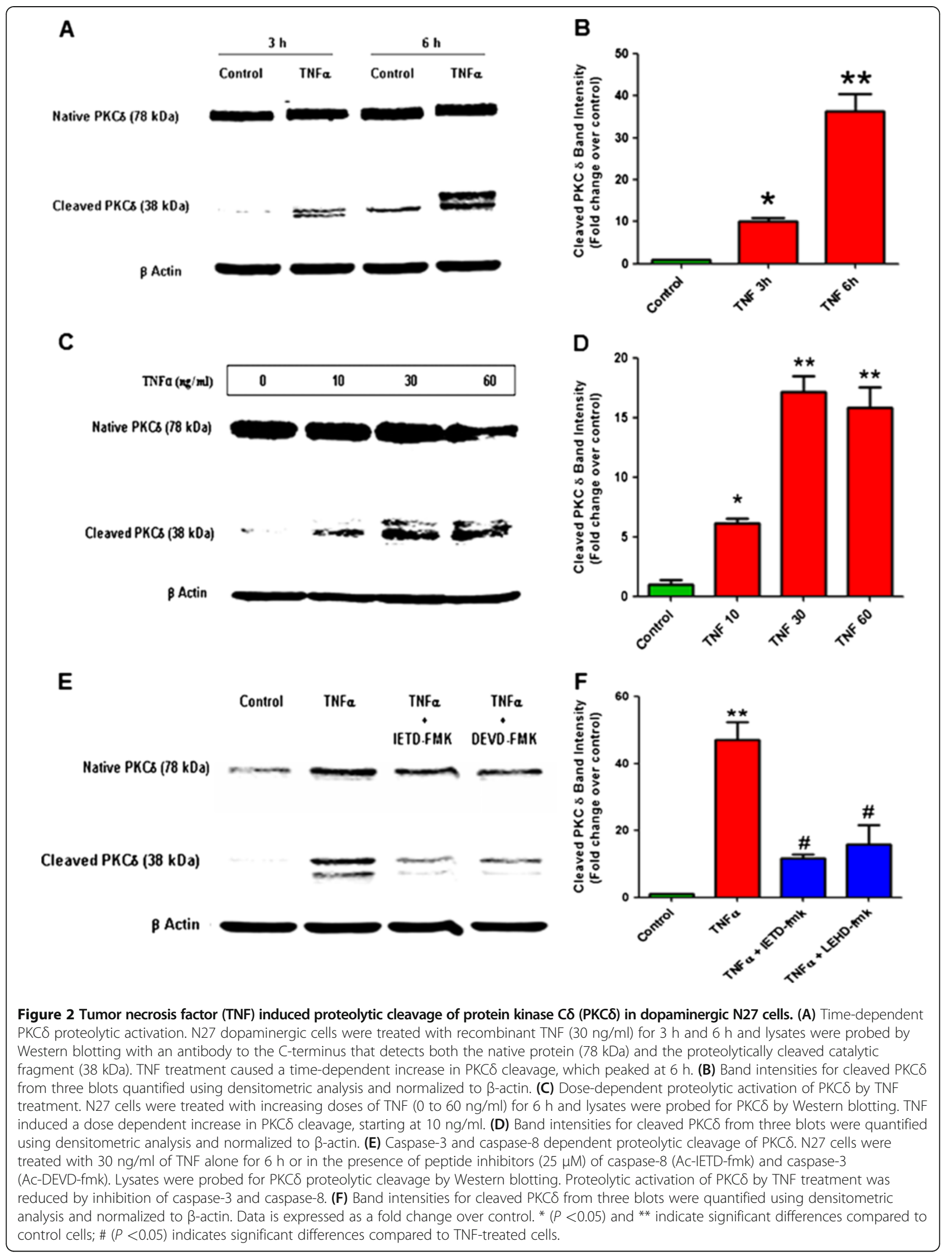




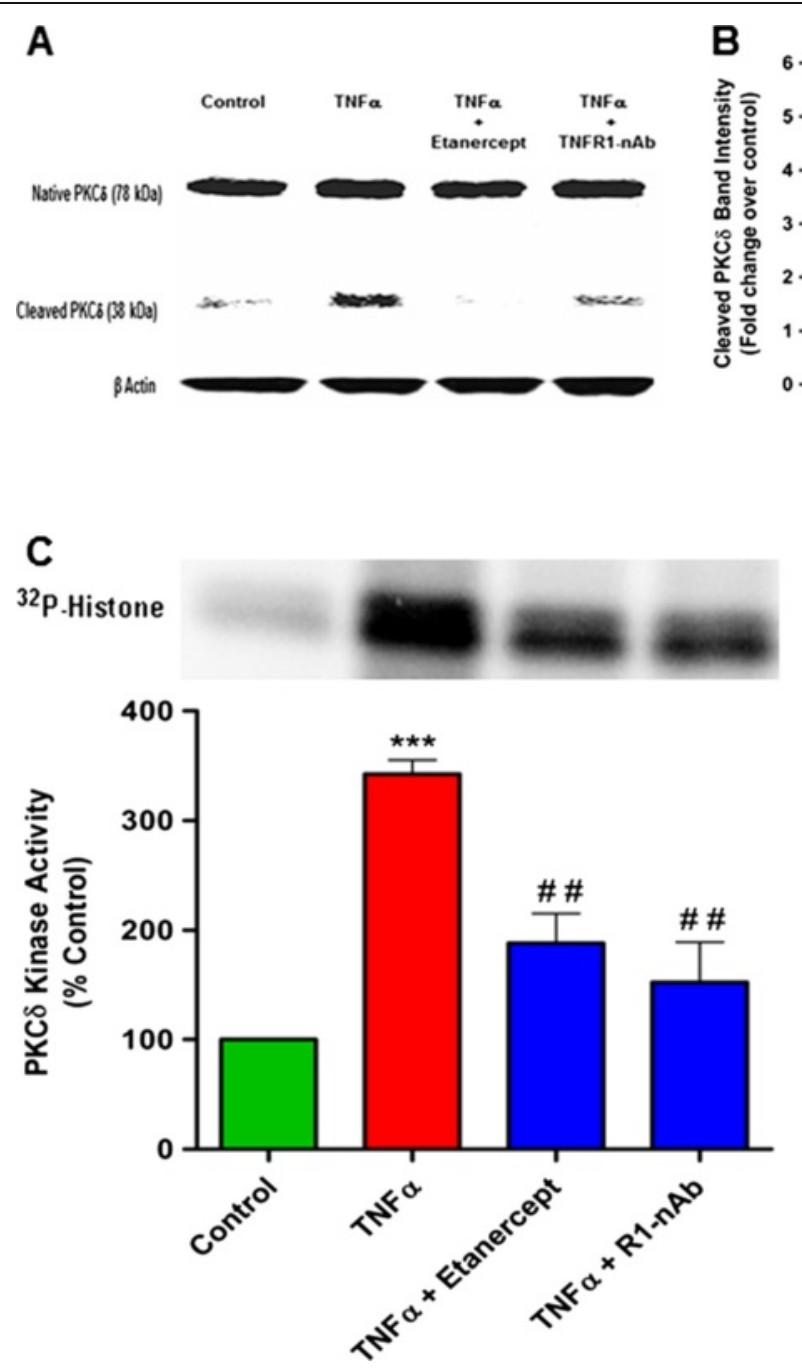

Figure 3 Proteolytic cleavage and activation of protein kinase $C \delta(P K C \delta)$ downstream of tumor necrosis factor receptor 1 (TNFR1) in N27 dopaminergic cells. (A) TNFR1-dependent proteolytic activation of PKC $\delta$. N27 cells were treated with tumor necrosis factor (TNF) (30 ng/ml) for $6 \mathrm{~h}$ or pretreated with either a TNFR1 neutralizing antibody (TNFR1-nAb, $20 \mu \mathrm{g} / \mathrm{ml}$ ) or etanercept $(5 \mu \mathrm{g} / \mathrm{ml}$ ) for 30 minutes and lysates were probed for PKC $\delta$ proteolytic cleavage by Western blotting. TNF induced strong proteolytic cleavage of PKC $\delta$ that could be blocked by neutralizing TNFR1 receptor signaling. (B) Band intensities for cleaved PKC $\delta$ were quantified using densitometric analysis and normalized to $\beta$-actin levels. (C) Immunoprecipitation (IP)-kinase assay for PKC $\delta$ activation. IP-kinase assays were performed on the same cell lysates used for Western blots. PKC $\delta$ was immunoprecipitated from $500 \mathrm{\mu g}$ of total protein from each sample and used for the in vitro kinase activity assay with a histone substrate and radiolabeled [ $\left.Y^{-}{ }^{32} \mathrm{P}\right]$ ATP. PKC $\delta$ activity was quantified using densitometric analysis of the ${ }^{32}$ P-histone band intensity and expressed as percent control. The proteolytic cleavage of PKC $\delta$ induced by TNF treatment was accompanied by a concomitant increase in kinase activity and was dependent on signaling through the TNFR1 receptor. A representative kinase assay gel is shown. Data represent the group mean \pm SEM of densitometric values obtained from three independent experiments. ${ }^{* *}(P<0.001)$ denotes significant differences compared to control cells and \#\# $(P<0.01)$ denotes significant differences compared to TNF-treated cells.

assays performed in the absence of lipid cofactors showed a robust increase in PKC $\delta$ kinase activity in TNF-treated samples, which could be attenuated by pretreatment with etanercept or by TNFR1 receptor neutralization (Figure 3C). These results demonstrate for the first time that PKC $\delta$ can be proteolytically activated in dopaminergic cells by a TNFR1-dependent signaling pathway, resulting in sustained activation of the kinase during TNF-induced cell death.

\section{PKC $\delta$ translocates to the nucleus during TNF-induced cell death}

Nuclear translocation of PKC $\delta$ has been shown to occur following proteolytic activation by apoptotic stimuli. A bipartite nuclear localization sequence (NLS) has been identified at the C-terminus (amino acids 611 to 623) of PKC $[46,47]$. The NLS is required for nuclear localization of both the full-length and proteolytically-cleaved forms of PKC $\delta$. However, previous studies have shown that 
proteolytic activation of $\mathrm{PKC} \delta$ by caspase-3 facilitates unmasking of the NLS, resulting in increased nuclear translocation of the catalytic fragment during apoptosis [47-49]. To further characterize the role of PKC $\delta$ in dopaminergic cell death induced by TNF, we used confocal microscopy to study the subcellular localization of PKCס. N27 cells were treated with TNF for $6 \mathrm{~h}$, the time point at which the highest level of cleaved PKC $\delta$ was detected, and confocal immunofluorescence was used to visualize the subcellular localization of PKC $\delta$. We detected prominent nuclear localization of PKC $\delta$ after $6 \mathrm{~h}$ in TNF-treated cells, while in control cells PKCס localized in the cytoplasm (Figure 4A). Nuclear translocation was also clearly evident in spatial fluorescence signal intensity plots (Figure 4B) for PKC $\delta$ (green channel) and the Hoechst nuclear stain (blue channel). Control cells had spatially distinct fluorescence signals for the nucleus and $\mathrm{PKC}$, showing that $\mathrm{PKC} \delta$ is largely localized outside the nucleus. However in TNF-treated cells, the spatial fluorescence signals had the same pattern along the $\mathrm{XY}$ plane. Interestingly, in addition to the overall increase in nuclear localization with TNF treatment, we also observed punctuate staining of PKC $\delta$ at distinct locations around the perinuclear region (shown in $60 \times$ magnification and labeled with red arrows). The nuclear localization of PKC $\delta$ following

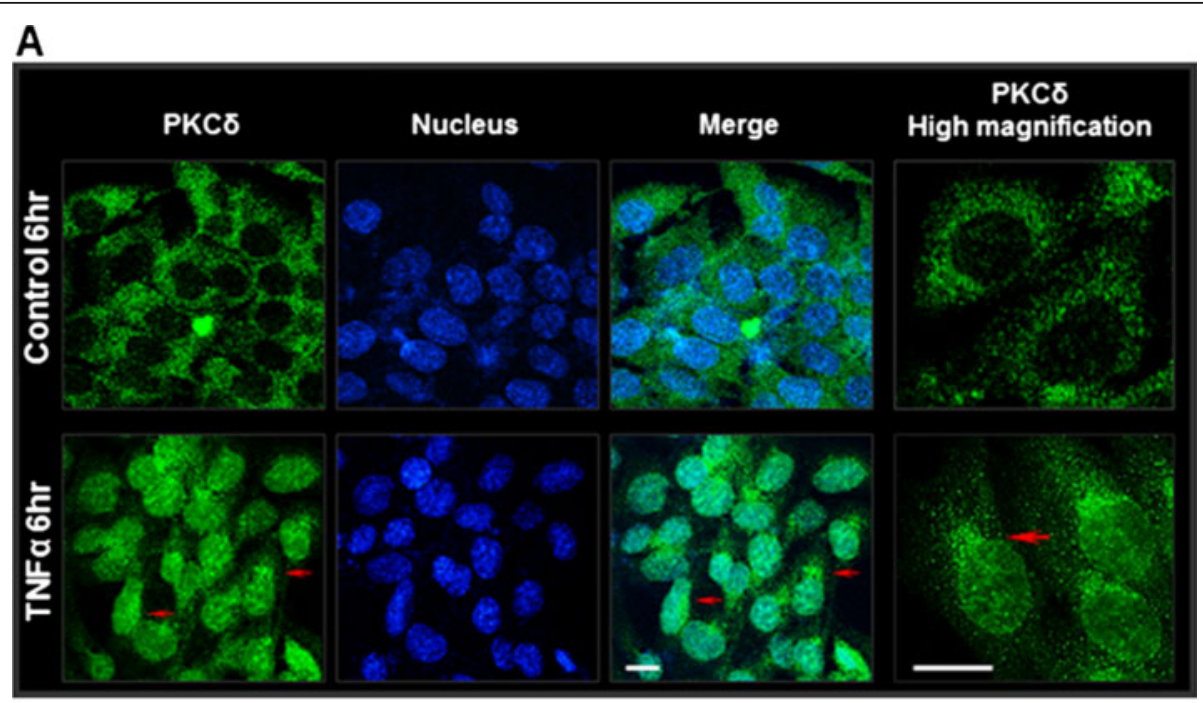

B

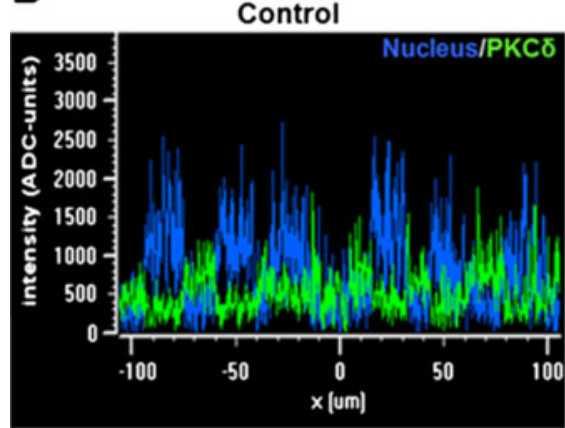

TNFa

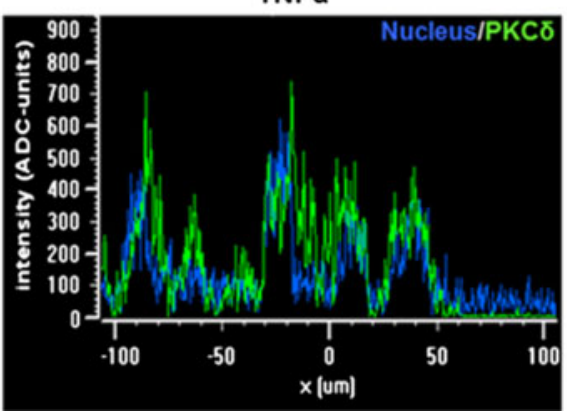

Figure 4 Protein kinase C $\delta$ (PKC $)$ translocates to the nucleus during tumor necrosis factor (TNF) treatment. (A) Confocal imaging of PKC $\delta$ localization. N27 cells were treated with TNF for $6 \mathrm{~h}$ and processed for immunocytochemistry using a rabbit polyclonal antibody that recognizes both the native and cleaved form of PKC $\delta$. An Alexa-488 dye-tagged secondary antibody was used to visualize PKC $\delta$ (green), and the nucleus was stained using the TOPRO-3 dye (blue). In untreated controls (top panel), PKC $\delta$ was distinctly localized to the cytosol. In TNF-treated cells (lower panel), a distinct localization of PKC $\delta$ to the nucleus and the perinuclear region is seen. Scale bars are 20 microns. High magnification images (right panel) of PKC immunofluorescence staining in N27 cells showing PKC $\delta$ accumulation within the nucleus and at distinct spatial locations at the perinuclear region following TNF treatment (red arrows). Representative images are shown; experiments were repeated three times using different secondary antibodies for validation. (B) Fluorescence spatial intensity plots along a representative XY plane for PKC $\delta$ localization (green channel) and the nucleus (blue channel) were obtained using the Nikon EZC1 image analysis software. Control images show a distinct spatial localization of green and blue fluorescence intensities in the XY plane indicative of cytosolic PKC $\delta$ localization. In TNF-treated cells a spatial colocalization of green and blue fluorescence signals is evident indicating nuclear translocation of PKC $\delta$. 
TNF treatment further points to an important role for this kinase in dopaminergic degeneration during TNF toxicity.

\section{Overexpression of a cleavage-resistant mutant} (PKC $\delta^{\text {D327A }}-$ CRM) or siRNA knockdown of PKC $\delta$ protects against TNF-induced dopaminergic cell death

To determine whether TNF-induced PKC $\delta$ activation contributes to the cell death process in dopaminergic cells, we used siRNA suppression of PKC $\delta$ and a caspase-3 cleavage-resistant mutant of PKC $\delta$ (PKC $\left.\delta^{\text {D327A }}-\mathrm{CRM}\right)$. First, N27 cells were transfected with siRNA to PKC $\delta$ or scramble siRNA and incubated for $24 \mathrm{~h}$ to allow for optimal suppression of PKC $\delta$ protein levels, which we validated by Western blotting (Figure 5B). The transfected cells were then treated with TNF for $16 \mathrm{~h}$ and processed for the DNA fragmentation assay. In N27 cells transfected with scramble siRNA, TNF caused a significant increase in DNA fragmentation, while the PKC $\delta$ siRNA transfected cells were protected from cell death (Figure 5A). These results indicate that $\mathrm{PKC} \delta$ is required for TNF-induced apoptosis in dopaminergic cells and that genetic or pharmacological modulation of $\mathrm{PKC} \delta$ may effectively attenuate TNF-induced neurotoxicity. To evaluate the significance of the PKC $\delta$ proteolytic cleavage events during proapoptotic TNF signaling, we used N27 cells

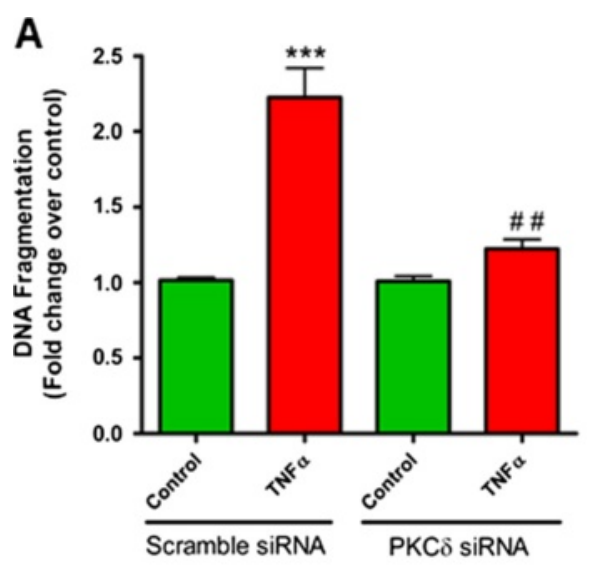

B

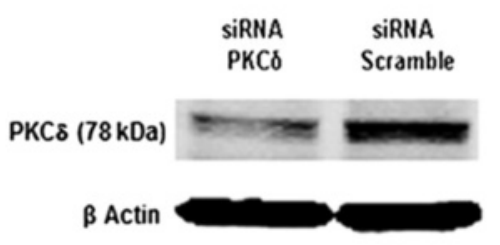

C

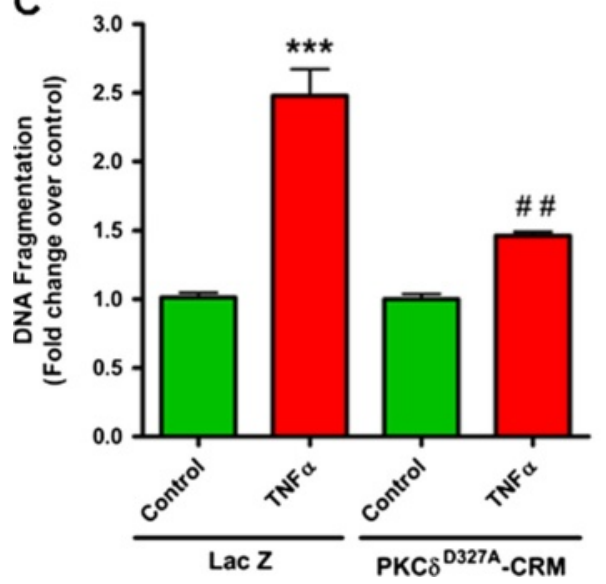

D

Phase Contrast

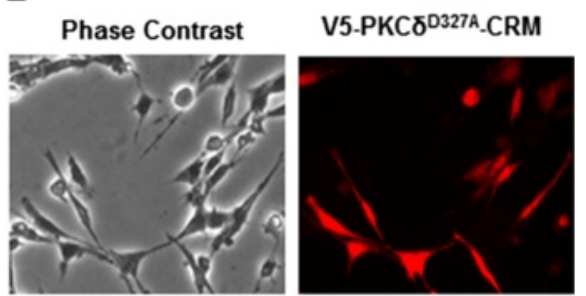

Figure 5 Knockdown of protein kinase $\mathrm{C} \delta$ (PKC $\delta$ ) with siRNA and overexpression of the PKC $\delta$ proteolytic cleavage-resistant mutant (PKC $\delta^{\text {D327A }}-$ CRM) protects against tumor necrosis factor (TNF) toxicity. (A) DNA fragmentation assay in siRNA transfected cells. N27 cells transfected with either siRNA to PKC $\delta$ or scrambled control siRNA were treated with TNF for $16 \mathrm{~h}$ and processed for the DNA fragmentation ELISA. Raw values were normalized to protein concentrations and expressed as the fold change over the respective controls. TNF-induced DNA fragmentation was significantly reduced in PKC $\delta$ siRNA transfected cells. (B) Suppression of the PKC $\delta$ protein levels by siRNA was confirmed by Western blotting. (C) DNA fragmentation assay in N27 cells overexpressing the cleavage-resistant PKC $\delta$ mutant protein (PKC $\delta^{\text {D327A }}-$ CRM). N27 cells stably expressing the cleavage-resistant PKC $\delta$ mutant or the $\beta$-galactosidase (LacZ) control gene were treated with TNF for $16 \mathrm{~h}$ and processed for the DNA fragmentation assay. Expression of the mutant PKC $\delta$ protein was confirmed by imaging the V5 tag by immunocytochemistry. (D) DNA fragmentation induced by TNF was attenuated in N27 cells expressing the caspase-3 cleavage-resistant mutant protein, indicating the proteolytic cleavage is a necessary event for TNF toxicity in these cells. Data represent the group mean \pm SEM, $n=6$ to 8 per group and experiments were repeated three times. ${ }^{* *}(P<0.001)$ indicates significant differences with TNF treatment compared to controls in scramble siRNA and LacZ expressing cells; \#\# $(P<0.01)$ indicates significant differences between the two TNF treatment groups. 
overexpressing a mutant $\mathrm{PKC} \delta$ protein resistant to proteolytic cleavage ( $\left.\mathrm{PKC} \delta^{\mathrm{D} 327 \mathrm{~A}}-\mathrm{CRM}\right)$ by caspase-3 due to a point mutation at the cleavage site. N27 cells that stably express either the cleavage-resistant PKC $\delta$ mutant or the LacZ protein (Figure 5D) were established as described previously [32]. The cells were treated with TNF for $16 \mathrm{~h}$ and processed for DNA fragmentation. As shown in Figure 5C, TNF treatment caused a 2.5 -fold increase in DNA fragmentation in LacZ cells, while cells expressing the $\mathrm{PKC} \delta^{\mathrm{D} 327 \mathrm{~A}}-\mathrm{CRM}$ mutant were protected from TNF toxicity, indicating that proteolytic cleavage of $\mathrm{PKC} \delta$ is crucial for TNF-induced cell death. Together, these results demonstrate that $\mathrm{PKC} \delta$ functions as a proapoptotic kinase during TNF-induced dopaminergic neurotoxicity and that proteolytic cleavage of PKC $\delta$ by caspase- 3 downstream of TNF signaling is required for cell death.

\section{Primary dopaminergic neurons obtained from PKC $\delta$} knockout (-I-) mice are protected from TNF neurotoxicity In order to extend our results from the previous mechanistic studies with the dopaminergic N27 clonal cell model to dopaminergic neurons, we used primary mouse ventral mesencephalic dopaminergic neuron cultures. We established primary mesencephalic neuronal (>95\% glial-free) cultures from $\mathrm{PKC} \delta$ wild type $(+/+)$ and knockout (-/-) mice to study the role of PKC $\delta$ in mediating TNF-induced dopaminergic neurodegeneration. Dopaminergic neurotoxicity was assessed by dopamine uptake assays and by TH-positive cell counting. As shown (Figure 6B,C), TNF exposure caused around $50 \%$ decrease in dopamine uptake and $\mathrm{TH}$-positive cell counts in cultures from PKC $\delta$ wild type $(+/+)$ mice, consistent with previous reports of dopaminergic neurotoxicity in similar model systems $[17,26]$. However, in primary neuron cultures obtained from PKC $\delta$ knockout (-/-) mice, TNF induced only around a $20 \%$ reduction in dopamine uptake and $\mathrm{TH}$-positive neuron counts, indicating that dopaminergic neurons from PKC $\delta$ knockout mice were resistant to TNF toxicity. In addition to functional measurement of TNF neurotoxicity by dopamine uptake, we also performed double labeling immunofluorescence morphometric analysis using $\mathrm{TH}$ as a marker for dopaminergic neurons and MAP-2 as a pan-neuronal marker. Untreated cultures from both PKC $\delta$ wild type $(+/+)$ and knockout $(-/-)$ mice had similar numbers of dopaminergic neurons and displayed extensive branched neurites and normal cell bodies (Figure 6A). In TNF-treated cultures, fewer TH-positive neurons with smaller cell bodies and a clear loss of neurites were evident in cultures from $\mathrm{PKC} \delta$ wild type $(+/+)$ mice. In contrast, dopaminergic neurons in cultures from PKC $\delta$ knockout (-/-) mice displayed visible branched neurites and more numerous cell bodies with normal morphology (Figure 6A lower panel), demonstrating significant protection against TNF toxicity in these cultures.

\section{PKC $\delta$ is activated by proteolytic cleavage in the mouse substantia nigra following stereotaxic infusion of LPS}

Next, we sought to extend the significance of our results obtained with the N27 dopaminergic cell culture model and primary neurons to an in vivo model of dopaminergic degeneration relevant to neuroinflammation. We selected the widely used stereotaxic LPS injection model of neuroinflammation-induced dopaminergic degeneration for our experiments $[17,35,50,51]$. In this model, a single injection of LPS into the rodent substantia nigra elicits a sustained, localized neuroinflammatory response resulting in a delayed loss of dopaminergic neurons in the SNpc. We stereotaxically injected C57bl6 mice with a single dose of $5 \mu \mathrm{g}$ LPS into the substantia nigra and sacrificed them 14 days later, the time at which significant dopaminergic degeneration occurs in this model [35]. The SN tissue was dissected and probed for proteolytic activation of PKC $\delta$ using Western blotting and IP-kinase assays. As shown in Figure 7A, mice that received saline injections did not show proteolytic activation of PKC $\delta$ in the SN, while LPSinjected mice showed strong proteolytic cleavage of $\mathrm{PKC} \delta$ at 14 days. The PKC $\delta$ Western blots were reprobed for tyrosine hydroxylase to confirm dissection of the substantia nigra region. As expected, the LPS-injected mice had decreased $\mathrm{TH}$ protein levels (Figure 7A), indicative of increased dopaminergic degeneration in this model at 14 days [35,50]. We also used PKC $\delta$ IP-kinase assays with a histone substrate on nigral tissue samples from LPSinjected and saline-injected mice. In nigral tissues from LPS-injected mice, we detected substantially higher PKC $\delta$ kinase activity compared to saline injected controls (Figure 7C), demonstrating that the proteolytic cleavage of PKC $\delta$ resulted in activation of the kinase in vivo. Equal protein loading and accurate dissection of the nigral tissue was confirmed by Western blotting for $\beta$-actin and $\mathrm{TH}$, respectively. Together, these results demonstrate for the first time that protein kinase $C \delta$ can be activated by proteolytic cleavage in the substantia nigra following LPSinduced neuroinflammation.

\section{Discussion}

In this study, we identify $\mathrm{PKC} \delta$ as a novel signaling mediator downstream of TNF-induced toxicity in dopaminergic neurons and demonstrate that proteolytic activation of PKC $\delta$ regulates dopaminergic degeneration induced by TNF (Depicted schematically in Figure 8). We also demonstrate for the first time, the proteolytic activation of PKC $\delta$ in the mouse substantia nigra by neuroinflammatory mechanisms during LPS-induced dopaminergic degeneration. The proteolytic activation of PKC $\delta$ by neuroinflammatory insults via the extrinsic 

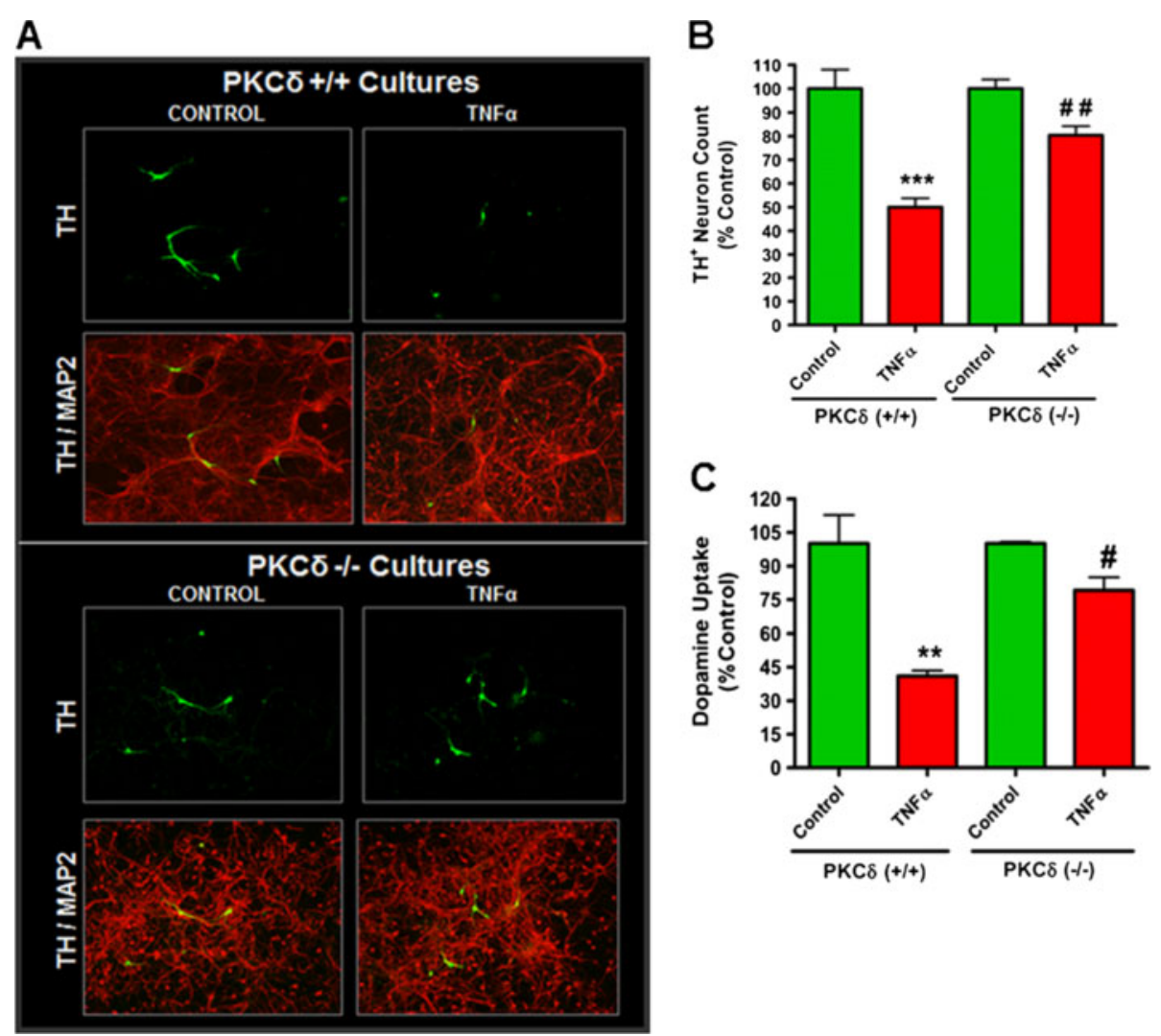

Figure 6 Primary dopaminergic neurons in EVM cultures from protein kinase C $\delta$ knockout (PKC $\delta-/-)$ mice are protected against tumor necrosis factor (TNF) toxicity. Primary mouse EVM neuronal cultures were treated with recombinant TNF ( $30 \mathrm{ng} / \mathrm{ml}$ ) in supplement-free neurobasal medium. TNF was re-added $24 \mathrm{~h}$ later for a total treatment time of $48 \mathrm{~h}$. PKC $\delta$ wild-type (PKC $\delta+/+$ ) and knockout (PKC $\delta-/-)$ EVM cultures were treated in parallel. (A) Immunocytochemistry for tyrosine hydroxylase (TH)-positive neurons. Dopaminergic neurons were identified by TH staining (green) and microtubule-associated protein 2 (MAP-2) (red) was used as a pan-neuronal marker. Images were acquired at $20 \times$ magnification. Representative fields are shown for each treatment. In the TNF-treated group, extensive loss of neurites and degeneration of dopaminergic neurons is evident in cultures from PKC $\delta$ wild-type (+/+) mice (top panel) whereas cultures from PKC $\delta$ knockout $(-/-)$ mice had visible branched neurites, more numerous cell bodies and were resistant to degeneration induced by TNF (lower panel). (B,C) TH-positive neuron counts and dopamine uptake assays. (B) Dopaminergic neurons were identified by tyrosine hydroxylase labeling, and the number of TH-positive neurons from 12 random fields per well were counted at $20 \times$ magnification for each treatment group. (C) The uptake of tritiated $\left[{ }^{3} \mathrm{H}\right]$ dopamine was determined in cultures from PKC $\delta$ wild-type (WT) and knockout mice. The values for non-specific uptake of dopamine obtained in the presence of mazindol were subtracted as background and the data expressed as percent control. Data represent the group mean $\pm S E M, n=4$ to 6 per group and experiments were repeated three times. ${ }^{* *} P<0.001$ indicates a significant difference between control and TNF-treated groups in PKC $\delta$ wild type cultures. \# $(P<0.05)$ and \#\# $(P<0.01)$ indicate a significant difference between TNF-treated groups in PKC $\delta$ wild-type and PKC $\delta$ knockout (-/-) cultures.

apoptotic pathway has not been studied, therefore it is essential to elucidate the mechanisms underlying progressive degeneration of dopaminergic neurons by chronic neuroinflammatory processes involving TNF and other neurotoxic mediators [52,53]. Based on the substantial literature supporting a degenerative role for TNF during dopaminergic cell death in PD models, we hypothesized that PKC $\delta$ can be proteolytically activated downstream of canonical TNF death receptor signaling by caspase-3 in dopaminergic neurons. Since proteolytic cleavage of PKC $\delta$ by caspase- 3 typically results in persistent activation of the kinase as an apoptotic effector, we reasoned that blocking proapoptotic PKC $\delta$ signaling could protect against TNF toxicity.
The results from our mechanistic studies using N27 rat dopaminergic cells indeed demonstrate for the first time that soluble TNF induces a time-dependent and dose-dependent proteolytic cleavage of PKC $\delta$ by a caspase- 8 and caspase- 3 signaling pathway, indicative of canonical TNF death receptor signaling via caspase-8. Using the anti-TNF drug Etanercept and neutralizing antibodies to the TNFR1 ( $\mathrm{p} 55$ ) death receptor, we show that proteolytic cleavage of PKC $\delta$ by soluble TNF is dependent on TNFR1 signaling and is accompanied by a substantial increase in PKC $\delta$ kinase activity (Figure 3), consistent with proteolytic activation. Previous reports from our laboratory and other independent research 

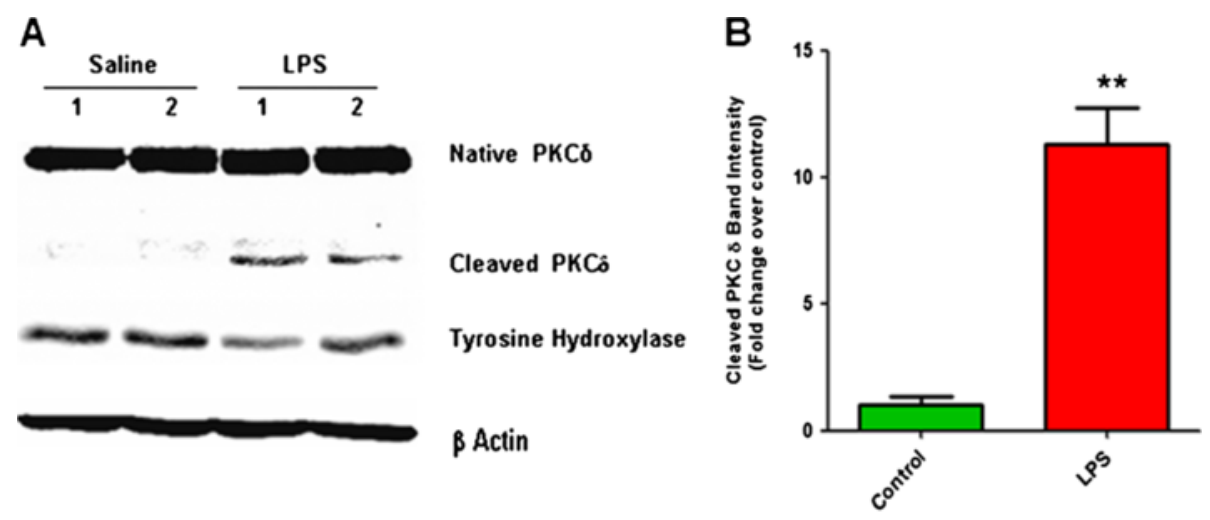

C

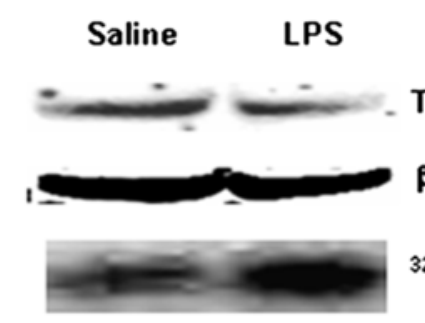

Tyrosine Hydroxylase

\section{B Actin}

${ }^{32} \mathrm{P}$ Histone

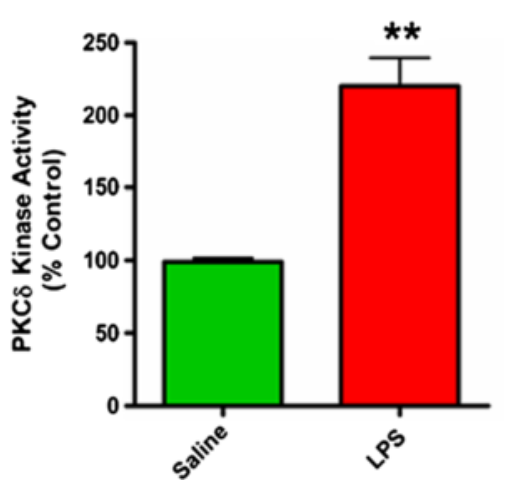

Figure 7 Proteolytic activation of protein kinase $\mathrm{C} \delta(\mathrm{PKC} \delta)$ in the mouse substantia nigra during LPS-induced dopaminergic degeneration. C57BL/6 mice were stereotaxically injected with a single dose of lipopolysaccharide (LPS) $(5 \mu \mathrm{g})$ or saline in the substantia nigra (SN) to elicit dopaminergic degeneration. Mice were sacrificed after 14 days. (A) Proteolytic cleavage of PKC $\delta$ in mouse substantia nigra tissue. Western blots were performed on nigral tissue lysates obtained from mice stereotaxically injected with either LPS or saline. Strong proteolytic cleavage of PKC $\delta$ is seen in LPS-injected mice and was essentially absent in the saline-injected animals. Blots were also probed for tyrosine hydroxylase and $\beta$-actin to confirm accurate dissection of the nigral tissue and equal protein loading respectively. (B) PKC $\delta$ cleaved band intensity was quantified by densitometric analysis after normalization to $\beta$-actin ( $n=4$ to 6 mice per group). (C) PKC $\delta$ kinase activity in mouse substantia nigra tissue. PKC $\delta$ IP-kinase assays were performed on nigral tissue lysates. Kinase activity was quantified by densitometric analysis of the ${ }^{32} \mathrm{P}-$ histone bands ( $n=4$ mice per group). A representative kinase gel is shown. Western blots of tyrosine hydroxylase and $\beta$-actin were performed on the same lysates to verify accurate dissection of the nigral tissue. Data represent the group mean \pm SEM. ${ }^{* *}(P<0.01)$ indicates a significant difference between saline and LPS-injected mice.

groups have shown that $\mathrm{PKC} \delta$ proteolytic activation contributes to apoptosis induced by diverse neurotoxic stimuli that converge on the intrinsic mitochondrial apoptotic pathway primarily through intracellular oxidative stress mechanisms [21-24,31,32,54-56]. Taken together, our present results suggest that proteolytic activation of PKC $\delta$ could be a common effector of cell death via both intrinsic and extrinsic cascades in dopaminergic neurons.
Rapid and dynamic translocation to distinct subcellular locations following activation is a characteristic feature of PKC $\delta$ in different cell types, and typically delineates the unique functional role of this kinase [57]. Various substrates have been identified as targets of PKC $\delta$ phosphorylation in different subcellular locations that participate in a range of multiple cellular functions, from apoptosis to cell migration and activation of immune cells [58]. In particular, studies have demonstrated that 


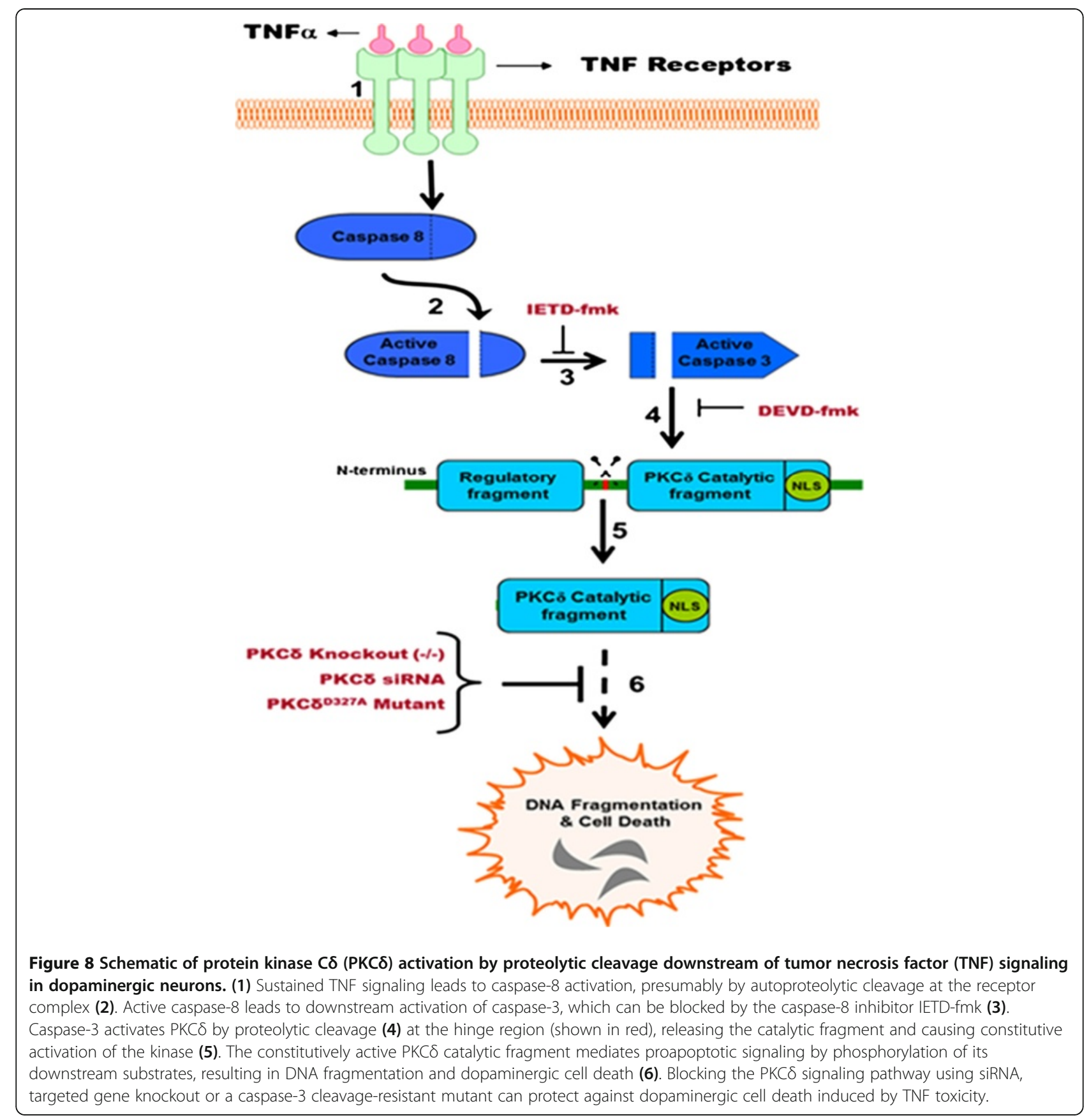

nuclear translocation of PKC $\delta$ is required for induction of apoptosis and is driven by a bipartite nuclear localization sequence at its C-terminus [48,49,59]. Our confocal immunofluorescence experiments reveal a distinct localization of $\mathrm{PKC} \delta$ to the nucleus $6 \mathrm{~h}$ after TNF treatment, the time point at which maximum proteolytic cleavage of PKC $\delta$ was evident, consistent with its proapoptotic function (Figure 4). While intense PKC $\delta$ staining is evident throughout the nucleus in TNF-treated cells, there is also a distinct pattern of accumulation of PKC $\delta$ at specific sites around the perinuclear region and within the nucleus. Interestingly, in a previous study, TNF superfamily ligands, such as BAFF (B cell-activating factor belonging to the TNF family), have been shown to prevent nuclear accumulation of full length $\mathrm{PKC} \delta$ and thus prolong cell survival in B cells [60]. The substrates of PKC $\delta$ and the functional significance of nuclear localization of the kinase during neuroinflammation are currently under investigation in our laboratory. However, the kinetics of $\mathrm{PKC} \delta$ proteolytic activation and its translocation to the nucleus observed in our present study, both indicate of a 
proapoptotic role for PKC $\delta$ downstream of TNF. Indeed, suppressing total $\mathrm{PKC} \delta$ protein levels using siRNA or blocking proteolytic activation using a $\mathrm{PKC} \delta$ cleavageresistant mutant ( $\left.\mathrm{PKC} \delta^{\mathrm{D} 327 \mathrm{~A}}-\mathrm{CRM}\right)$ affords robust protection against TNF neurotoxicity (Figure 5). The results from our mechanistic studies are further supported by our experiments in primary mesencephalic neuronal cultures treated with soluble TNF, which induces degeneration of dopaminergic neurons in these cultures $[17,26]$. Although TNF was less toxic to primary dopaminergic neurons than the classical Parkinsonian neurotoxicant 1-methyl-4-phenylpyridinium $\left(\mathrm{MPP}^{+}\right)$ [21], we observed a substantial reduction in $\mathrm{TH}$ neuron numbers and functional impairment as determined by dopamine uptake studies in cultures from PKC $\delta$ wild type $(+/+)$ mice (Figure 6). Importantly, dopaminergic neurons in mesencephalic cultures obtained from PKC $\delta$ knockout (-/-) mice were protected against TNF toxicity, indicating that $\mathrm{PKC} \delta$ signaling is essential for dopaminergic degeneration triggered by TNF.

Evidence from previous studies [17,26] and our own results here, indicate that TNF can induce dopaminergic neurotoxicity by a direct mechanism, possibly via the TNFR1 (TNFRSF1) death receptor, which has been shown to be highly expressed on these cells. However, additional lines of evidence suggest that TNF can also contribute to dopaminergic degeneration indirectly by potentiating microglial reactive oxygen species (ROS) and other neurotoxic mediators, which can increase local oxidative stress levels in the SNpc [19,52,61]. The elevated TNF levels in the SN in both animal models and human PD patients and the concomitant microglial activation indicate that potentiation of microglial neurotoxic responses by TNF likely occurs in vivo, although it may not be the primary mechanism of dopaminergic neurotoxicity, as suggested by McCoy et al. using mixed neuron-glial cultures. A chronic increase in TNF levels in the nigrostriatal system may drive the progressive loss of compromised and vulnerable dopaminergic neurons in the pro-oxidant environment of the SNpc, both by TNF apoptotic signaling and by potentiation of microglial neurotoxic responses, including ROS and RNS production $[17,19,26,52,62]$. Nonetheless, our data demonstrating that $\mathrm{PKC} \delta$ is proteolytically activated in the substantia nigra in the neuroinflammatory LPS model (Figure 7) of PD, implicate proapoptotic $\mathrm{PKC} \delta$ signaling as a common downstream effector of dopaminergic cell death triggered by convergent neuroinflammatory mechanisms involving TNF and other neurotoxic mediators in the mouse brain.

\section{Conclusions}

Despite extensive research into the etiology of PD for several decades, a cogent basis for the vulnerability and extensive loss of $\mathrm{SNpc}$ dopaminergic neurons still remains elusive. The emerging consensus is that $\mathrm{PD}$ results from complex interactions between environmental, genetic and cellular processes that induce dopaminergic cell death over time $[3,63]$. This highlights the multifactorial nature of the disease process and underscores the importance of identifying therapeutic targets that are relevant across these multiple mechanisms of disease pathogenesis. While oxidative stress, mitochondrial dysfunction and proteasomal impairment have been identified as causative factors that can trigger dopaminergic cell death; reactive microgliosis and dysregulated neuroinflammation can sustain this process and result in progressive neurodegeneration $[6,52,53]$. We previously showed that proteasomal impairment, mitochondrial dysfunction and oxidative stress induce proteolytic activation of PKC $\delta$ to drive dopaminergic cell death $[24,45,64]$. Our results herein suggest a crucial role for proapoptotic $\mathrm{PKC} \delta$ signaling during dopaminergic cell death induced by extracellular TNF and neuroinflammatory mechanisms. Pharmacological targeting of PKC $\delta$ with kinase inhibitors such as rottlerin has shown efficacy in protecting against dopaminergic degeneration in vitro and in the MPTP mouse model of PD [21,55]. Our results from this study provide a rationale for pharmacological targeting of PKC $\delta$ to mitigate neuroinflammatory events associated with progressive degeneration of dopaminergic neurons in PD. Taken together, our results herein suggest that proteolytic activation of $\mathrm{PKC} \delta$ could be a common downstream target for multiple mediators of dopaminergic degeneration by both extrinsic and intrinsic cell death mechanisms, making it an attractive therapeutic target during the progressive phase of PD.

\section{Competing interests}

The authors declare that they have no competing interests.

\section{Acknowledgements}

This study was supported by grants from the National Institutes of Health NS 65167, NS078247 and NS74443.

\section{Authors' contributions}

RG designed studies, performed experiments and wrote the manuscript. VA assisted with study design and manuscript editing. AGK and AK conceived the study, the coordination of experiments and editing of the manuscript drafts. All authors were involved in editing drafts of the manuscript and approved the final manuscript.

Received: 12 November 2011 Accepted: 27 April 2012 Published: 27 April 2012

\section{References}

1. Moore DJ, West AB, Dawson VL, Dawson TM: Molecular pathophysiology of Parkinson's disease. Annu Rev Neurosci 2005, 28:57-87.

2. Schapira AH: Neurobiology and treatment of Parkinson's disease. Trends Pharmacol Sci 2009, 30:41-47.

3. Obeso JA, Rodriguez-Oroz MC, Goetz CG, Marin C, Kordower JH, Rodriguez M, Hirsch EC, Farrer M, Schapira AH, Halliday G: Missing pieces in the Parkinson's disease puzzle. Nat Med 2010, 16:653-661. 
4. Hirsch EC, Hunot S: Neuroinflammation in Parkinson's disease: a target for neuroprotection? Lancet Neurol 2009, 8:382-397.

5. Tansey MG, Goldberg MS: Neuroinflammation in Parkinson's disease: its role in neuronal death and implications for therapeutic intervention. Neurobiol Dis 2010, 37:510-518.

6. Glass CK, Saijo K, Winner B, Marchetto MC, Gage FH: Mechanisms underlying inflammation in neurodegeneration. Cell 2010, 140:918-934.

7. Bialecka M, Klodowska-Duda G, Kurzawski M, Slawek J, Gorzkowska A, Opala G, Bialecki P, Sagan L, Drozdzik M: Interleukin-10 (IL10) and tumor necrosis factor alpha (TNF) gene polymorphisms in Parkinson's disease patients. Parkinsonism Relat Disord 2008, 14:636-640.

8. Nishimura M, Mizuta I, Mizuta E, Yamasaki S, Ohta M, Kaji R, Kuno S: Tumor necrosis factor gene polymorphisms in patients with sporadic Parkinson's disease. Neurosci Lett 2001, 311:1-4.

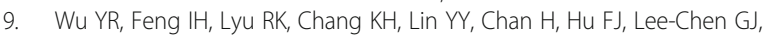
Chen CM: Tumor necrosis factor-alpha promoter polymorphism is associated with the risk of Parkinson's disease. Am J Med Genet B Neuropsychiatr Genet 2007, 144B:300-304.

10. Boka G, Anglade P, Wallach D, Javoy-Agid F, Agid Y, Hirsch EC: Immunocytochemical analysis of tumor necrosis factor and its receptors in Parkinson's disease. Neurosci Lett 1994, 172:151-154.

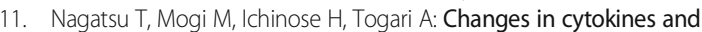
neurotrophins in Parkinson's disease. J Neural Transm Suppl 2000, 60:277-290.

12. Mogi M, Harada M, Riederer $P$, Narabayashi H, Fujita K, Nagatsu T: Tumor necrosis factor-alpha (TNF-alpha) increases both in the brain and in the cerebrospinal fluid from parkinsonian patients. Neurosci Lett 1994, 165:208-210.

13. Barcia C, de Pablos V, Bautista-Hernandez V, Sanchez-Bahillo A, Bernal I, Fernandez-Villalba E, Martin J, Banon R, Fernandez-Barreiro A, Herrero MT: Increased plasma levels of TNF-alpha but not of IL1-beta in MPTPtreated monkeys one year after the MPTP administration. Parkinsonism Relat Disord 2005, 11:435-439.

14. Mogi M, Togari A, Tanaka K, Ogawa N, Ichinose H, Nagatsu T: Increase in level of tumor necrosis factor (TNF)-alpha in 6-hydroxydopaminelesioned striatum in rats without influence of systemic L-DOPA on the TNF-alpha induction. Neurosci Lett 1999, 268:101-104.

15. Sriram K, Matheson JM, Benkovic SA, Miller DB, Luster MI, O'Callaghan JP: Mice deficient in TNF receptors are protected against dopaminergic neurotoxicity: implications for Parkinson's disease. FASEB J 2002, 16:1474-1476.

16. Ferger B, Leng A, Mura A, Hengerer B, Feldon J: Genetic ablation of tumor necrosis factor-alpha (TNF-alpha) and pharmacological inhibition of TNF-synthesis attenuates MPTP toxicity in mouse striatum. J Neurochem 2004, 89:822-833.

17. McCoy MK, Martinez TN, Ruhn KA, Szymkowski DE, Smith CG, Botterman BR, Tansey KE, Tansey MG: Blocking soluble tumor necrosis factor signaling with dominant-negative tumor necrosis factor inhibitor attenuates loss of dopaminergic neurons in models of Parkinson's disease. J Neurosci 2006, 26:9365-9375.

18. McCoy MK, Ruhn KA, Martinez TN, McAlpine FE, Blesch A, Tansey MG: Intranigral lentiviral delivery of dominant-negative TNF attenuates neurodegeneration and behavioral deficits in hemiparkinsonian rats. Mol Ther 2008, 16:1572-1579.

19. De Lella Ezcurra AL, Chertoff M, Ferrari C, Graciarena M, Pitossi F: Chronic expression of low levels of tumor necrosis factor-alpha in the substantia nigra elicits progressive neurodegeneration, delayed motor symptoms and microglia/macrophage activation. Neurobiol Dis 2010, 37:630-640.

20. Zhang D, Kanthasamy A, Yang Y, Anantharam V, Kanthasamy A: Protein kinase $C$ delta negatively regulates tyrosine hydroxylase activity and dopamine synthesis by enhancing protein phosphatase-2A activity in dopaminergic neurons. J Neurosci 2007, 27:5349-5362.

21. Zhang D, Anantharam V, Kanthasamy A, Kanthasamy AG: Neuroprotective effect of protein kinase $C$ delta inhibitor rottlerin in cell culture and animal models of Parkinson's disease. J Pharmacol Exp Ther 2007, 322:913-922

22. Anantharam V, Kitazawa M, Wagner J, Kaul S, Kanthasamy AG: Caspase-3-dependent proteolytic cleavage of protein kinase Cdelta is essential for oxidative stress-mediated dopaminergic cell death after exposure to methylcyclopentadienyl manganese tricarbonyl. J Neurosci 2002, 22:1738-1751.

23. Hanrott K, Murray TK, Orfali Z, Ward M, Finlay C, O'Neill MJ, Wonnacott S: Differential activation of PKC delta in the substantia nigra of rats following striatal or nigral 6-hydroxydopamine lesions. Eur J Neurosci 2008, 27:1086-1096.
24. Kaul S, Kanthasamy A, Kitazawa M, Anantharam V, Kanthasamy AG: Caspase-3 dependent proteolytic activation of protein kinase $C$ delta mediates and regulates 1-methyl-4-phenylpyridinium (MPP+)-induced apoptotic cell death in dopaminergic cells: relevance to oxidative stress in dopaminergic degeneration. Eur J Neurosci 2003, 18:1387-1401.

25. Clarkson ED, Rosa FG, Edwards-Prasad J, Weiland DA, Witta SE, Freed CR, Prasad KN: Improvement of neurological deficits in 6-hydroxydopaminelesioned rats after transplantation with allogeneic simian virus 40 large tumor antigen gene-induced immortalized dopamine cells. Proc Natl Acad Sci USA 1998, 95:1265-1270.

26. McGuire SO, Ling ZD, Lipton JW, Sortwell CE, Collier TJ, Carvey PM: Tumor necrosis factor alpha is toxic to embryonic mesencephalic dopamine neurons. Exp Neurol 2001, 169:219-230.

27. Gordon R, Hogan CE, Neal ML, Anantharam V, Kanthasamy AG, Kanthasamy A: A simple magnetic separation method for high-yield isolation of pure primary microglia. J Neurosci Methods 2011, 194:287-296.

28. Sherer TB, Betarbet R, Stout AK, Lund S, Baptista M, Panov AV, Cookson MR, Greenamyre JT: An in vitro model of Parkinson's disease: linking mitochondrial impairment to altered alpha-synuclein metabolism and oxidative damage. J Neurosci 2002, 22:7006-7015.

29. Kaul S, Anantharam V, Yang Y, Choi CJ, Kanthasamy A, Kanthasamy AG: Tyrosine phosphorylation regulates the proteolytic activation of protein kinase Cdelta in dopaminergic neuronal cells. J Biol Chem 2005, 280:28721-28730.

30. Bradford MM: A rapid and sensitive method for the quantitation of microgram quantities of protein utilizing the principle of protein-dye binding. Anal Biochem 1976, 72:248-254.

31. Yang Y, Kaul S, Zhang D, Anantharam V, Kanthasamy AG: Suppression of caspase-3-dependent proteolytic activation of protein kinase $C$ delta by small interfering RNA prevents MPP +-induced dopaminergic degeneration. Mol Cell Neurosci 2004, 25:406-421.

32. Latchoumycandane C, Anantharam V, Kitazawa M, Yang Y, Kanthasamy A, Kanthasamy AG: Protein kinase Cdelta is a key downstream mediator of manganese-induced apoptosis in dopaminergic neuronal cells. J Pharmacol Exp Ther 2005, 313:46-55.

33. Liu B, Du L, Hong JS: Naloxone protects rat dopaminergic neurons against inflammatory damage through inhibition of microglia activation and superoxide generation. J Pharmacol Exp Ther 2000, 293:607-617.

34. Gao HM, Hong JS, Zhang W, Liu B: Distinct role for microglia in rotenoneinduced degeneration of dopaminergic neurons. J Neurosci 2002, 22:782-790.

35. Saijo K, Winner B, Carson CT, Collier JG, Boyer L, Rosenfeld MG, Gage FH, Glass CK: A Nurr1/CoREST pathway in microglia and astrocytes protects dopaminergic neurons from inflammation-induced death. Cell 2009, 137:47-59.

36. Sun F, Anantharam V, Zhang D, Latchoumycandane C, Kanthasamy A, Kanthasamy AG: Proteasome inhibitor MG-132 induces dopaminergic degeneration in cell culture and animal models. Neurotoxicology 2006, 27:807-815

37. Hartmann A, Hunot S, Michel PP, Muriel MP, Vyas S, Faucheux BA, MouattPrigent A, Turmel H, Srinivasan A, Ruberg M, Evan Gl, Agid Y, Hirsch EC: Caspase-3: A vulnerability factor and final effector in apoptotic death of dopaminergic neurons in Parkinson's disease. Proc Natl Acad Sci USA 2000, 97:2875-2880

38. Zhao X, Bausano B, Pike BR, Newcomb-Fernandez JK, Wang KK, Shohami E, Ringger NC, DeFord SM, Anderson DK, Hayes RL: TNF-alpha stimulates caspase-3 activation and apoptotic cell death in primary septohippocampal cultures. J Neurosci Res 2001, 64:121-131.

39. Mogi M, Harada M, Riederer P, Narabayashi H, Fujita K, Nagatsu T: Tumor necrosis factor-alpha (TNF-alpha) increases both in the brain and in the cerebrospinal fluid from parkinsonian patients. Neurosci Lett 1994, 165:208-210.

40. Le WD, Rowe DB, Jankovic J, Xie W, Appel SH: Effects of cerebrospinal fluid from patients with Parkinson disease on dopaminergic cells. Arch Neurol 1999, 56:194-200.

41. Dobbs RJ, Charlett A, Purkiss AG, Dobbs SM, Weller C, Peterson DW: Association of circulating TNF-alpha and IL-6 with ageing and parkinsonism. Acta Neurol Scand 1999, 100:34-41.

42. Zhang D, Kanthasamy A, Yang Y, Anantharam V: Protein kinase C delta negatively regulates tyrosine hydroxylase activity and dopamine 
synthesis by enhancing protein phosphatase-2A activity in dopaminergic neurons. J Neurosci 2007, 27:5349-5362.

43. Apostolatos H, Apostolatos A, Vickers T, Watson JE, Song S, Vale F, Cooper DR, Sanchez-Ramos J, Patel NA: Vitamin A metabolite, all-trans-retinoic acid, mediates alternative splicing of protein kinase $\mathrm{C}$ deltaVIII (PKCdeltaVIII) isoform via splicing factor SC35. J Biol Chem 2010, 285:25987-25995

44. Jiang K, Apostolatos AH, Ghansah T, Watson JE, Vickers T, Cooper DR, EplingBurnette PK, Patel NA: Identification of a novel antiapoptotic human protein kinase $\mathrm{C}$ delta isoform, PKCdeltaVIII in NT2 cells. Biochemistry 2008, 47:787-797.

45. Kanthasamy AG, Kitazawa M, Kanthasamy A, Anantharam V: Role of proteolytic activation of protein kinase Cdelta in oxidative stress-induced apoptosis. Antioxid Redox Signal 2003, 5:609-620.

46. DeVries TA, Neville MC, Reyland ME: Nuclear import of PKCdelta is required for apoptosis: identification of a novel nuclear import sequence. EMBO J 2002, 21:6050-6060.

47. 3Ghayur T, Hugunin M, Talanian RV, Ratnofsky S, Quinlan C, Emoto Y, Pandey P, Datta R, Huang Y, Kharbanda S, Allen H, Kamen R, Wong W, Kufe D: Proteolytic activation of protein kinase $C$ delta by an ICE/CED 3-like protease induces characteristics of apoptosis. J Exp Med 1996, 184:2399-2404

48. Humphries MJ, Ohm AM, Schaack J, Adwan TS, Reyland ME: Tyrosine phosphorylation regulates nuclear translocation of PKCdelta. Oncogene 2008, 27:3045-3053.

49. DeVries-Seimon TA, Ohm AM, Humphries MJ, Reyland ME: Induction of apoptosis is driven by nuclear retention of protein kinase $\mathrm{C}$ delta. $J$ Biol Chem 2007, 282:22307-22314.

50. Herrera AJ, Castano A, Venero JL, Cano J, Machado A: The single intranigral injection of LPS as a new model for studying the selective effects of inflammatory reactions on dopaminergic system. Neurobiol Dis 2000, 7:429-447.

51. Liu B, Jiang JW, Wilson BC, Du L, Yang SN, Wang JY, Wu GC, Cao XD, Hong JS: Systemic infusion of naloxone reduces degeneration of rat substantia nigral dopaminergic neurons induced by intranigral injection of lipopolysaccharide. J Pharmacol Exp Ther 2000, 295:125-132.

52. Block ML, Zecca L, Hong JS: Microglia-mediated neurotoxicity: uncovering the molecular mechanisms. Nat Rev Neurosci 2007, 8:57-69.

53. Whitton PS: Inflammation as a causative factor in the aetiology of Parkinson's disease. Br J Pharmacol 2007, 150:963-976.

54. Cunningham RL, Giuffrida A, Roberts JL: Androgens induce dopaminergic neurotoxicity via caspase-3-dependent activation of protein kinase Cdelta. Endocrinology 2009, 150:5539-5548.

55. Kanthasamy AG, Anantharam V, Zhang D, Latchoumycandane C, Jin H, Kau S, Kanthasamy A: A novel peptide inhibitor targeted to caspase-3 cleavage site of a proapoptotic kinase protein kinase C delta (PKCdelta) protects against dopaminergic neuronal degeneration in Parkinson's disease models. Free Radic Biol Med 2006, 41:1578-1589.

56. Sun F, Kanthasamy A, Song C, Yang Y, Anantharam V, Kanthasamy AG: Proteasome inhibitor-induced apoptosis is mediated by positive feedback amplification of PKCdelta proteolytic activation and mitochondrial translocation. J Cell Mol Med 2008, 12:2467-2481.

57. Gomel R, Xiang C, Finniss S, Lee HK, Lu W, Okhrimenko H, Brodie C: The localization of protein kinase Cdelta in different subcellular sites affects its proapoptotic and antiapoptotic functions and the activation of distinct downstream signaling pathways. Mol Cancer Res 2007, 5:627-639.

58. Steinberg SF: Distinctive activation mechanisms and functions for protein kinase Cdelta. Biochem J 2004, 384:449-459.

59. Reyland ME: Protein kinase Cdelta and apoptosis. Biochem Soc Trans 2007, 35:1001-1004

60. Mecklenbrauker I, Kalled SL, Leitges M, Mackay F, Tarakhovsky A: Regulation of B-cell survival by BAFF-dependent PKCdelta-mediated nuclear signalling. Nature 2004, 431:456-461.

61. Sriram K, Matheson JM, Benkovic SA, Miller DB, Luster MI, O'Callaghan JP. Deficiency of TNF receptors suppresses microglial activation and alters the susceptibility of brain regions to MPTP-induced neurotoxicity: role of TNF-alpha. FASEB J 2006, 20:670-682.

62. Qin L, Wu X, Block ML, Liu Y, Breese GR, Hong JS, Knapp DJ, Crews FT: Systemic LPS causes chronic neuroinflammation and progressive neurodegeneration. Glia 2007, 55:453-462.

63. Sulzer D: Multiple hit hypotheses for dopamine neuron loss in Parkinson's disease. Trends Neurosci 2007, 30:244-250.
64. Jin H, Kanthasamy A, Anantharam V, Rana A, Kanthasamy AG: Transcriptional regulation of pro-apoptotic protein kinase Cdelta: implications for oxidative stress-induced neuronal cell death. J Biol Chem 2011, 286:19840-19859.

doi:10.1186/1742-2094-9-82

Cite this article as: Gordon et al:: Proteolytic activation of proapoptotic kinase protein kinase $C \delta$ by tumor necrosis factor a death receptor signaling in dopaminergic neurons during neuroinflammation. Journal of Neuroinflammation 2012 9:82.

\section{Submit your next manuscript to BioMed Central and take full advantage of:}

- Convenient online submission

- Thorough peer review

- No space constraints or color figure charges

- Immediate publication on acceptance

- Inclusion in PubMed, CAS, Scopus and Google Scholar

- Research which is freely available for redistribution

Submit your manuscript at www.biomedcentral.com/submit
C Biomed Central 